\title{
From Banks to Shanks: the history of employee awards for patented inventions under the Patents Act 1977
}

\author{
Phillip Johnson* \\ Professor of Commercial Law, Cardiff University
}

The introduction of statutory awards for inventors in the Patents Act 1977 was highly controversial. Using original archival sources and parliamentary debates, the political battles that raged both in public and behind the scenes are explored. Central to the policy development was a report by a government-appointed Working Party; yet, until now, this report and its recommendations have not been published. The report represents a compromise agreement between representatives of both employers and employees. It was used by the government as the main defence of its policy. Using this report, and the contemporary political discussions, the small number of decisions of the comptroller and the courts will be examined to see if they reflect the balance struck by the Working Party, thereby providing a history of statutory employee awards in the United Kingdom as they have evolved over the last fifty years.

Keywords: employee inventions, awards to inventors, Patents Act 1977, patent history

\section{INTRODUCTION}

In 1977 what became the Patents Act 1977 made its way through Parliament. The Bill was uncontentious, so much so that the opposition agreed ${ }^{1}$ to support the ratification of

* I would like to thank Mike Jewess and Alison Smith for their help accessing material, and Trevor Cook and the anonymous referees for their comments on an earlier draft. This article made use of various archive sources: the Trades Union Congress (TUC) and Confederation of British Industry (CBI) archives at the Modern Records Centre, Warwick University (CBI: MSS.200 and TUC: MSS.292); the departmental material held at the National Archive (BT/); Parliamentary Counsel's papers (AM1/) which have been accessioned to the National Archive, but have been retained by the Office of Parliamentary Counsel (OPC); the Intellectual Property Office - formerly, the Patent Office (PO) - files which have been retained with their original file numbers (IPCD) (these may be accessioned into the National Archive in due course, but the original file number is usually recorded on the National Archive catalogue; albeit some material in the current file may be destroyed in the process if it is felt not to be of public interest in the future); the IP Federation files (formerly, the Trade Marks, Patents and Designs Federation (TMPDF)) are held by in the Bodleian Library, Oxford (Bod); the archive of the Chartered Institute of Patent Attorneys is very limited and held no relevant material. The following additional acronyms have been used: Institute of Patentees and Inventors (IPI); Ministry of Defence (MOD); Foreign and Commonwealth Office (FCO); Department of Trade (and Industry) Solicitors, who are the legal advisers to the Patent Office (DTI Sols); and the Lord Chancellor's Department (LCD).

1. Letter, Terrance Skemp (OPC) to Anthony Parry (FCO), 18 November 1976; Letter, Parry to Skemp, 22 November 1976: AM1/2440; also see Letter, Ron Bowen (PO) to M John Fretwell 
the European Patent Convention immediately after Second Reading of the Bill, ${ }^{2}$ contrary to the usual practice of waiting until the implementing legislation was enacted. But the provisions dealing with employee inventions, and employee compensation in particular, were far from uncontentious. ${ }^{3}$ So much so that a Working Party comprising employers and employees was set up to reach a compromise agreement. Its report was central to both policy development before the Bill was presented to Parliament and subsequently to justify the proposed law to the House. Even after a compromise had been reached, statutory employee awards remained controversial, and few at the time ${ }^{4}$ would have expected that the first compensation judgment would not be handed down for over a decade, ${ }^{5}$ that the first actual award of compensation would have to wait a further twenty years ${ }^{6}$ and that the second award would be a decade later still. ${ }^{7}$ Indeed, there have only ever been eight final decisions on employee compensation in over forty years. ${ }^{8}$ Yet these provisions, which have barely been litigated, have a rich and detailed history to explore.

\section{BACKGROUND}

The idea of employers paying an award for inventions developed by their employees dates back to the 1940s. ${ }^{9}$ After the Second World War, the Swan Committee was constituted to consider patent law, and in its Final Report it examined the issue of employee inventions by setting out three cases. First, where the employee develops

(FCO), 30 December 1976; Letter, Philip Bovey (DTI Sols) to Peter Petrice (FCO), 20 January 1977: AM1/2441; also see CIPA, CBI, ICC, TMPDF Memorandum, 10 February 1976 Bod: B48/F2.

2. In the United Kingdom, there are usually five stages for a Bill to pass: First Reading, Second Reading, Committee, Report and Third Reading. It then goes through the same process in the second house; the UK ratified the EPC on 3 March 1977 after the Second Reading in the House of Lords; the ratification was mentioned during the Second Reading in the House of Commons: John Nott, HC Deb, 25 May 1977, Vol 932, col 1451.

3. When the Bill moved from the Lords to the Commons the contentious issues were listed as follows: (i) employee inventors; (ii) the secrecy provisions (now, Patents Act 1977 s 22 and s 23); (iii) patent term (particularly for pharmaceutical patents); (iv) disclosures between the date of filing and the application being made (ie whether to retain effect of Patents Act 1949, s 52; now Patents Act 1977, s 6); (v) the use of the term European Patent Attorney (originally Patents Act 1977, s 85; now Copyright, Designs and Patents Act 1988, s 277); and (vi) advisors to assist the Comptroller when acting judicially (see pp 150-51): see Ron Bowen, PUSS Office Minute No 431: IPCD 41343.

4. The Report of the TMPDF Working Group constituted in 1978 suggested it would be a 'number of years' before the court gave any decision on the meaning of 'outstanding': see Report 'Employee Inventions' (C.6/78), p 3: Bod: B70/F1; a slightly shorter version of the report is at: Monthly Report, March 1978, Pt 1, p 2: Bod B62/F4.

5. GEC Avionics Patents (1989) [1992] RPC 107.

6. Kelly v GE Healthcare [2009] EWHC 181 (Pat), [2009] RPC 12.

7. Shanks $v$ Unilever [2019] UKSC 45, [2019] 1 WLR 5997.

8. Ibid; Kelly v GE Healthcare [2009] EWHC 181 (Pat); MemCo-Med Ltd's Patent (Trett's Application) [1992] RPC 403; Re British Steel's Patent (Monk's Application) [1992] RPC 117; Re GEC Avionics [1992] RPC 107; Fellerman v Thorn EMI (O/11/96) (renewed as Fellerman v Electrolux (O/75/98)); Milner v Dixons International (O/164/98); Drage v Garrison Ltd (O/44/97). 9. In the nineteenth century, it had been the case that employees owned their inventions (see, for instance, Heald's Patents (1891) 8 RPC 429 at 430) but eventually a term was implied into the employment contract: for an early example, see Printing and Numerical Registering Co $v$ Sampson (1874-5) LR 19 Eq 462 at 462; see generally, Jeremy Phillips and Michael Hoolahan, Employees' Inventions in the United Kingdom: Law and Practice (ESC Publishing 1982), p 44. 
something outside the course of his or her duties and the patent belongs entirely to the employee. Secondly, where the employee is employed to invent so the patent belongs entirely to the employer. Thirdly, and finally, inventions where the employer and employee may be entitled to share the benefit of the invention. ${ }^{10}$

An attempt to provide for the third case was adopted in section 56(2) of the Patents Act $1949,{ }^{11}$ which enabled the court to apportion the benefit of an invention between the employer and the employee. Yet the House of Lords held in Patchett v Sterling Engineering ${ }^{12}$ that, absent an agreement, ${ }^{13}$ an invention could either be owned by the employer or owned by the employee but there was no middle ground allowing it to be jointly owned. This meant that no apportionment of the benefit could ever happen, making section 56(2) a 'dead letter'. ${ }^{14}$ A decade later, the Patents (Employees' Inventions) Bill $1965^{15}$ was introduced to mitigate the effect of Patchett. ${ }^{16}$ It had been intended to give an employee a 'just proportion of the fruits of his invention' ${ }^{17}$ by setting out certain considerations to assess the benefit. ${ }^{18}$ It passed the House of Lords but limped only to a Second Reading in the Commons. The Bill was never resurrected, and the matter was in abeyance for a couple of years.

\subsection{The Banks Committee}

The Banks Committee, which was appointed in 1967 and reported in $1970,{ }^{19}$ considered employee inventions as part of its overall review of patent law. ${ }^{20}$ While the Trades Union Congress (TUC) ${ }^{21}$ submitted evidence advocating a system similar to that of Germany for the United Kingdom, ${ }^{22}$ the Committee followed the representations of industry, ${ }^{23}$ and said that a statutory scheme was not the most appropriate way forward, albeit encouraging voluntary schemes. ${ }^{24}$ It did, however, recommend

10. [Swan Report], Final Report of Department Committee (1946-7 Cmd 7206), [25-27].

11. It was technically introduced by the pre-consolidation Patents and Designs Act 1949, s 39.

12. (1955) 72 RPC 50.

13. A rare example of a case where there may have been such an agreement is Pashley $v$ Linotype (1903) 20 RPC 633.

14. Lord Rhodes, HL Deb, 27 April 1965, Vol 265, col 508.

15. Patents (Employee Inventions) Bill 1965 (1964-5 HC Papers 161), Vol 3, p 861 (the final version); there was also an earlier attempt to address the issue of employee inventions with the Patents and Designs Bill 1934 (1933-4 HC Papers 136), Vol 3, p 423.

16. Lord Rhodes, HL Deb, 27 April 1965, Vol 265, col 508.

17. Ibid.

18. Cl 1(3) (which was amended in Committee); see HL Deb, 1 June 1965, Vol 266, col 1029-1045.

19. Appointment: HC Deb, 10 May 1967, Vol 746, col 241W; Presented: 226 CJ 43; 203 LJ

39 (14 Jul 1970). It was thus appointed by Harold Wilson's Labour government but reported after Edward Heath's Conservatives came to power: [Banks], The British Patent System: Report of the Committee to Examine the Patent System and Patent Law (Cmnd 4407) ('Banks Report').

20. Banks Report, Chapter 16.

21. The TUC was, and is, the organization which represents all (member) trade unions collectively.

22. The submission is included in the Report of the 100th Annual Trades Union Congress (TUC 1968), pp 329-30 (No 267).

23. Banks Report, [469].

24. Banks Report, [465 and 469]; in 2004 the Minister said inaccurately that the compensation regime was based on Banks: Gerry Sutcliffe, SC D Deb, 15 June 2004, col 19. 
that a contract which diminishes the rights of employees under the common law should not be enforceable. ${ }^{25}$ Initially, the government intended to introduce a bill to implement the Committee's recommendations ${ }^{26}$ without taking account of the developments in Europe ${ }^{27}$ and this desire was maintained through to the 1973/4 parliamentary session. ${ }^{28}$ But in 1974 , the new Labour government ${ }^{29}$ wanted to expand the scope of the bill to cover employee inventions.

\subsection{White Paper: Patent Law Reform}

The White Paper Patent Law Reform ${ }^{30}$ was published by the Labour government on 16 April $1975 .{ }^{31}$ It summarized Banks before going on say: ${ }^{32}$

the Government is prepared to give further consideration to the introduction of a statutory award scheme for employee inventors if there is substantial evidence to show that this would be fairer to employees generally, and would welcome further public comment.

The Labour Party's need to reconsider the issue followed extensive agitation by the Institute of Patentees and Inventors (IPI) ${ }^{33}$ and, more significantly, concern expressed by unions, with the Association of Broadcasting Staff managing to get a resolution passed at the TUC Congress in $1971 .^{34}$

\section{THE LOBBY}

The White Paper galvanized interest groups into action. The IPI, ${ }^{35}$ the Confederation of British Industry $(\mathrm{CBI})^{36}$ and the TUC were particularly concerned with employee

25. Banks Report, [469].

26. And only those recommendations (ie go no further): TMPDF Council Minutes, 9 February 1973, p 2: Bod B42/F1.

27. Exceptionally, it was proposed that instead of the Bill being drafted by Parliamentary Counsel an experiment would be undertaken to instruct a member of the Patents bar to draft it. Vivien Price was briefed but after many months had not started work so it went back to Parliamentary Counsel: Letter, Gerald Ryder (DTI Sols) to Sir John Fiennes (OPC), 16 June 1971; Letter, Ryder to Fiennes, 26 October 1971; Memorandum, Francis Bayly (DTI Sols) to Derrick Rippengal (OPC), 20 November 1972; Letter, Humphrey Cotman (DTI Sols) to Sir Anthony Stainton (OPC), 30 November 1972; Letter, Cotman to Thomas Hetherington (AGO), 13 December 1972: BT 103/1712.

28. Letter, Geoffrey Howe (Minister of Trade) to Lord Hailsham (Lord Chancellor), [21] February 1973: NA BT 103/1712.

29. Labour formed a minority government after the first election of 1974, but after the second election that year it gained a small majority.

30. (1975) Cmnd 6000.

31. 231 CJ 353 (16 April 1975).

32. (1975) Cmnd 6000, [37].

33. See Cyril Greenstreet (International Nikel, CBI), Working Party Meeting, 15 August 1975, p 2: MSS.200/C/3/COM/7/3.

34. Report of the 103rd Annual Trades Union Congress (TUC 1971), pp 461-4 (the motion was for the government to implement the Banks Report recommendations).

35. There have been numerous other intellectual property organizations with the acronym IPI; these should not be confused: all references here are to the Institute of Patentees and Inventors. 36. The CBI was, and is, a business organization which claims to speak for British business collectively (both large and small). 
inventions. While other organizations, such as the Chartered Institute of Patent Agents (CIPA) ${ }^{37}$ were more interested in the implementation of the European Patent Convention. ${ }^{38}$ The TUC was probably the most active in pushing for extensive protection for employee inventors, with the CBI and the Trade Mark, Patents and Designs Federation (TMPDF) advocating for employers. Yet it was the dedicated work of the Institute of Patentees and Inventors who got the discussion started following the publication of the White Paper.

\subsection{The Institute of Patentees and Inventors}

The IPI was, and is, a representative organization for individual inventors. Soon after the White Paper was published it drew up some preliminary observations which it circulated in July $1975^{39}$ before producing a report a month later. ${ }^{40}$ It was the first mover and, with its inventor perspective, it strongly advocated for the need to introduce a Statutory Award Scheme, describing it as 'long overdue' ${ }^{41}$ Its starting principle was that an inventor, whether employed or not, should get some reward for his or her achievements, ${ }^{42}$ in particular a positive right. ${ }^{43}$ The basic premise being that an employee was losing a property right when an employer was entitled to the patent and this should dictate the entire approach. ${ }^{44}$ It went on to reject the German system for rewarding employee inventors (with its precise mathematical formula) ${ }^{45}$ as too expensive and complicated, rather it was in favour of the more imprecise Swedish model. ${ }^{46}$

The IPI set out certain principles ${ }^{47}$ but key was the second principle - that an inventor should be entitled to an unwaivable right of compensation in the invention, ${ }^{48}$ which should be assessed by reference to the 'duties of the employee, his salary and position,

37. Now the Chartered Institute of Patent Attorneys.

38. CIPA sent a note to the Patent Office before the Second Reading setting out issues it considered important but employee inventions were not mentioned: Note from the Chartered Institute of Patent Agents, 11 January 1977: AM1/2441.

39. A copy date stamped 28 July 1975 was received by the CBI: MSS.200/C/3/EMP/10/3.

40. Industry considered the arguments presented to be easy to rebut: TMPDF Council Minutes, 22 September 1975, pp 1-2: Bod: B23/F1.

41. IPI, Report on the Government White Paper 'Patent Law Reform', 14 August 1975, p 6: MSS.200/C/3/COM/7/3 and also in MSS.200/C/3/EMP/10/3; for an industry response see Second Draft, Comments on the Report of the Institute of Patentees and Inventors (C28/75): Bod: B48/F1.

42. IPI, Report on 'Patent Law Reform', p 7.

43. Ibid, pp 10-16.

44. See ibid, p 14.

45. German Employee's Inventions Act 1951 (ArbnErfG); for a near contemporary discussion see Matthias Ruete, 'The German Employee-Invention Law: An Outline' in Jeremy Phillips (ed), Employee's Inventions: A Comparative Study (Fernsway Publications 1981) Ch 7.

46. Swedish Patent Law 1949, s 3; see Finn Rausing, 'The Swedish Law of Employee's Inventions' in Jeremy Phillips (ed), Employee's Inventions: A Comparative Study (Fernsway Publications 1981), Ch 4.

47. IPI, Report on 'Patent Law Reform', Appendix 3. Many related to ancillary matters, such as a requirement to report the invention to the employer (Principle 3), rules about blocking patents (Principle 5), patenting expenses (Principle 6), tax relief for compensation payments (Principle 6), and that university employees should be outside the scheme (Principle 9).

48. The IPI thought that compensation should be payable for an invention whether there was a patent or it was protected by the law of trade secrets (confidence): Principle 4. 
the nature of the rights claimed by the employer and the value of the invention' ${ }^{49}$ This meant that those employed to invent would get negligible awards ${ }^{50}$ as they had already received their salary. ${ }^{51}$ In terms of procedure, the award, the IPI said, should be made by an Industrial Tribunal, ${ }^{52}$ with appeals to the proposed new Patents Court. ${ }^{53}$

\subsection{The Confederation of British Industry}

The CBI had last considered the issue of employee awards in 1968, when, adopting the view of the AIPPI, ${ }^{54}$ it said they were not a fit subject for detailed statute law. ${ }^{55}$ However, soon after the White Paper was published in 1975, the CBI set up the Employee Inventions Working Party, chaired by John Carr. It resisted awards from the outset, Carr opening with the statement that statutory awards would 'do more harm than good' and that the evidence showed they 'would not be welcomed by employees'. ${ }^{56}$ The Working Party's clear direction of travel meant that the first draft of its Report was produced after only one meeting. ${ }^{57}$ Its reasons to resist ranged from the narrow - providing for awards might turn the Patents Bill into contentious legislation to broad policy sweeps that awards for inventors would be the thin edge of the wedge and other areas of business (such as advertising and marketing) would follow. ${ }^{58}$ To support its stance that awards did not work, the CBI Working Party looked to abandoned voluntary schemes (for instance that of Westinghouse Brake and Signal Co) ${ }^{59}$ and 'token' schemes ${ }^{60}$ (like that at Esso where on filing an inventor received a bonus of $£ 10$ and a further $£ 15$ was paid on grant). ${ }^{61}$

Nevertheless, and despite the general sentiment, the CBI Working Party accepted that there might be 'hard cases' where normal relations between employees and employers would not achieve a fair share. ${ }^{62}$ Yet it said that such cases would be rare, highlighting

49. IPI, Report on 'Patent Law Reform', p 2.

50. Ibid, $\mathrm{p} 10$.

51. However, it was pointed out that a salary is paid for success as well as failure, so linking it only to success is unwarranted: IPI, Report on 'Patent Law Reform', p 13.

52. These were set up under the Industrial Training Act 1964 and their jurisdiction was expanded over the following years. They were renamed Employment Tribunals by the Employment Rights (Dispute Resolution) Act 1998.

53. IPI, Report on 'Patent Law Reform', Principle 8 (p 3).

54. Association Internationale pour la Protection de la Propriété Intellectuelle, The Inventions of Employees, Q40 (1967-III) AIPPI Yearbook 112.

55. Bruce Cawthra (CBI Legal Adviser), Employee Inventions Working Party, 4 August 1975, p 1 (which was also said to be the view of TMPDF; an extract of its submission to Banks was annexed): MSS.200/C/3/COM/7/3 also in MSS.200/C/3/EMP/10/3.

56. Minutes of CBI Working Party Meeting, 15 August 1975, p 2: MSS.200/C/3/COM/7/3.

57. The first draft is dated 19 August 1975: MSS.200/C/3/COM/7/3.

58. Minutes of CBI Working Party Meeting, 15 August 1975, p 2: MSS.200/C/3/COM/7/3.

59. CBI Working Party Report on Employee Inventions ('CBI Report'), p 2: MSS.200/C/3/ $\mathrm{COM} / 7 / 3$ also in MSS.200/C/3/EMP/10/3. There was a memo regarding the problems with the scheme, but it is not in the file.

60. The real reward coming from promotion and salary.

61. Esso Memorandum, Award to Inventors - Esso Research, 24 May 1961, pp 1-2: MSS.200/ C/3/COM/7/3 and MSS.200/C/3/EMP/10/3; the BBC had a similar token scheme: see Report of the 103rd Annual Trades Union Congress (TUC 1971), p 462.

62. It was also pointed out that due to the pay of many inventors the tax payable (which was as high as 98 per cent on those earning over $£ 20,000$ ) would lead to little real reward: Dr Harold Aspen (IBM), Note, 28 July 1975: MSS.200/C/3/COM/7/3. 
that the IPI had managed to identify only $20 .{ }^{63}$ These hard cases might, it was said, be confined to employee inventors who went 'beyond the call of duty' ${ }^{64}$ Any such cases, the CBI Working Party argued, could be remedied on the basis of an 'appeals procedure', whereby an employee who was not fairly dealt with by the employer could seek some financial redress from other means. ${ }^{65}$ In retrospect, it is difficult to see how this would differ from a statutory award scheme as only once internal procedures are exhausted would a statutory claim be brought. Nevertheless, the CBI Working Party identified what it saw as central problems with an award scheme, namely that most inventions were the work of a team ${ }^{66}$ and the result of an interactive process contrary to the 'lay' view that each invention is a one off. ${ }^{67}$ Some members of the CBI Working Party went further, seeing any new system as creating 'a damnable and unnecessary nuisance', 68 which, based on the (West) German experience, might require a dedicated team. ${ }^{69}$

\subsubsection{The CBI Working Party report}

The CBI Working Party ${ }^{70}$ reported on 24 September 1975 and sent its report to the Patent Office. ${ }^{71}$ Unsurprisingly it was not in favour of a statutory scheme. In line with its deliberations, it reported that it had been unable to find any case where an employer had not given an adequate reward to their employees, ${ }^{72}$ that inventions were usually evolutionary rather than revolutionary, and that they were developed by teams of scientists not remediable by individual awards. ${ }^{73}$ But the CBI Report accepted that there might be a very small number of 'hard' cases where an employee had made an invention of such importance that the normal way to remunerate employees was not possible. ${ }^{74}$ While these statements against employee awards

63. IPI, Report on 'Patent Law Reform', Appendix 1 (albeit it identified nine cases only); this is probably the document referred to in Jeremy Phillips and Michael Hoolahan, Employees' Inventions in the United Kingdom: Law and Practice (ESC Publishing 1982), p 49.

64. Glacier Metal Company Memorandum, p 2: MSS.200/C/3/COM/7/3 also in MSS.200/C/3/ $\mathrm{EMP} / 10 / 3$.

65. Minutes of CBI Working Party Meeting, 15 August 1975, p 3.

66. And the R\&D environment where they work: a point made by ICI: Letter, Anthony Willbourn to Linda Bagnall (CBI Company Affairs Legal), Employee Inventions Working Party, 13 August 1975: MSS.200/C/3/COM/7/3; a point also made during the passage of the Patents Act 2004: Lord Lyell, HL Deb, 8 March 2004, Vol 658, col GC 357; in Kelly the court accepted that rewarding some named inventors in a team but not others could be invidious: Kelly $v$ GE Healthcare [2009] EWHC 181 (Pat), [153 and 158].

67. Minutes of CBI Working Party Meeting, 15 August 1975, p 1: MSS.200/C/3/COM/7/3 and MSS.200/C/3/EMP/10/3; the 'lay' view was also adopted by IPI, Report on 'Patent Law Reform', p 11, citing Maurice Crews 'Three Patent Incentives - A Re-appraisal' (1961) 43 Journal of the Patent Office Society 554.

68. Letter, John Tyson (TMPDF President and Esso Engineering Services) to Linda Bagnall, Working Party on Employee Inventions, 27 August 1975: MSS.200/C/3/COM/7/3 also in MSS.200/C/3/EMP/10/3.

69. Ibid.

70. Its first meeting was on 15 August 1975: Letter to Members of Employee Inventions Working Party, 6 August 1975: MSS.200/C/3/COM/7/3. The second meeting was 9 September 1975.

71. Letter, Linda Bagnall to CBI Members, 7 October 1975: MSS.200/C/3/EMP/10/3.

72. CBI Report, $\mathrm{p} 1$.

73. CBI Report, p 2; a point raised in Parliament: Lord Nelson, HL Deb, 24 February 1977, Vol 380, col 409; John Nott, SC D Deb, 2nd Sitting, 30 June 1977, col 84.

74. CBI Report, $\mathrm{p} 2$. 
might seem self-serving in 1975, it turned out that over the next 45 years they were not far wrong.

\subsection{The Trade Marks, Patents and Designs Federation}

The Trade Marks, Patents and Designs Federation (TMPDF) (now the IP Federation) represented, and represents, the views of industry in intellectual property rights policy. Its interests were largely aligned with those of the CBI and there were even concerns expressed at the time that the two organizations should not speak with different voices. ${ }^{75}$ Its basic position had long been against statutory awards, and at the time of the White Paper its view was that awards would be inflationary, ${ }^{76}$ without increasing the number of worthwhile patents. ${ }^{77}$ They were also concerned awards would add additional complexity for businesses as well as putting pressure on them to file more applications. $^{78}$

\subsection{The Trades Union Congress}

The TUC submitted evidence to the Banks Committee proposing that an award scheme similar to that practised in Sweden or (West) Germany should be adopted in the United Kingdom. ${ }^{79}$ Even when this failed, it continued to push for the Banks recommendation on employee contracts to be implemented. This lobbying led to the TUC getting a seat on the Comptroller's Standing Advisory Committee, ${ }^{80}$ but it was the 1975 White Paper which really peaked its interest, ${ }^{81}$ and even though its engagement with patent matters was limited, the TUC played a pivotal role in the development of the policy.

\section{THE SAC WORKING PARTY}

On 22 March 1976 the Comptroller's Standing Advisory Committee (SAC) ${ }^{82}$ considered employee inventions, ${ }^{83}$ including the White Paper and the CBI Report. It was

75. See Draft Letter, John Aubrey to Campbell Adamson (CBI), 3 April 1975 (C10/75): Bod: B48/F1.

76. The government was fighting to keep inflation under control at the time (it had been 24.2 per cent in 1975; 16.5 per cent in 1976 and 15.8 per cent in 1977).

77. TMPDF Council Minutes, 12 September 1975, p 5: Bod: B43/F3.

78. TMPDF Comments on Chapter VI of White Paper on Patent Law Reform (C29/74), 9 September 1975: Bod: B48/F1.

79. See note 22.

80. Report of 103rd Annual Trades Union Congress (TUC 1971), pp 231-2 (No 341).

81. Report of 108th Annual Trades Union Congress (TUC 1976), p 328 (No 388).

82. The Standing Advisory Committee was proposed by Kenneth Johnson and Patrick Graham: see Extract of Letter to Scarman J, Law Commission, 1 April 1966; and invitations were sent out in May 1967: both BT 209/1354. The appointments were made at the same time as for the Banks Committee, with the SAC dealing with more pressing questions relating to international matters. The formation of the SAC was announced along with its scope, in The Times, 27 June 1967, p 17. The Banks Committee recommended that the SAC's remit should expand to cover all patent matters: Banks Report, [136].

83. There was an Interdepartmental Working Party on Awards for the Commercial Exploitation of Inventions and Technical Suggestions, 1975, which considered inventions made by Crown Servants. The full report is in IPCD: 41183 . 
apparent that, aside from the IPI, the position before the meeting was that most members were against the proposal ${ }^{84}$ and the meeting itself had been dominated by the TUC putting forward its position. ${ }^{85}$ Worse still, the discussion led to little consensus save, first, that should any statutory award be created it should be restricted to patented inventions from which benefit accrued and, secondly, that any new policy should not be included in any patents act. ${ }^{86}$

Following this difficult meeting, the Comptroller proposed to the Minister that a Working Party should be established. The Minister thought a scheme 'to provide some kind of incentive for inventiveness' for employees was important and, contrary to the Comptroller's suggestion, that for political reasons it should be in the Patents Bill $^{87}$ (the reasons included keeping it away from labour/employment legislation and avoiding having to deal with employee invention schemes being proposed as amendments to the Patents Bill). ${ }^{88}$ He therefore agreed to the formation of a Working Party on Employee Inventors ${ }^{89}$ comprising interested groups and members of the SAC. ${ }^{90}$ It had the following terms of reference:

... to consider further the idea of:

(I) Replacing the common law test by a statutory definition; and

(II) Providing for an allocation of the benefit of an invention where, although the rights lie with the employee, the circumstances are such that both the employer and employee can fairly be said to be entitled to a share in the benefit.

With a view to formulating the content of provisions which could be inserted in the projected Patents Bill.

It was not, therefore, within its terms of reference to debate the merits of whether there should be a statutory award system or not, but only what such a scheme should look like. ${ }^{91}$

84. Minutes of 29th Meeting of SAC, 22 March 1976: IPCD No 41183; also see TMPDF, Council Minutes, 12 March 1976, p 2: Bod: B42/F4.

85. TMPDF, Council Minutes, 9 April 1976, p 2: Bod: B42/F4 (George Doughty made one of 'his rare appearances' and 'monopolised discussion' with 'obsolete ideas').

86. Chair's Summary, Minutes of 29th Meeting of SAC, 22 March 1976, p 13; there was apparently a consensus for a more flexible model like that in Sweden: TMPDF, Council Minutes, 9 April 1976, p 2: Bod: B42/F4.

87. Industry tried to push back on this decision, but it was said to be non-negotiable: TMPDF Council Minutes, 10 September 1976, p 3: Bod: B42/F4; also see TMPF Council Minutes, 1 October 1976, p 5: Bod B2/F4.

88. TMPDF, Council Minutes, 9 July 1976, p 4: Bod B42/F4.

89. Note of Secretary of State Meeting to Discuss Patents Legislation, 8 June 1976 (Minute No 803): IPCD: 41183.

90. See Letter, Edward Armitage (Comptroller) to Cyril Wickham, 16 June 1976: MSS.292D/ 508/3. This also includes the terms of reference (copies of all letters inviting members are in IPCD: 41183) The Membership was John M Aubrey (British National Committee, International Chamber of Commerce/SAC), George Doughty (TUC), Leonard Cotterell (Institute of Patentees and Inventors/SAC), John Ellis (Mewburn Ellis and Co, Patent Agents/ SAC), Douglas Falconer QC (Bar Council/SAC), Cyril Wickham (SAC Chair), F Leo Killeen (Civil Service Department), Austin Devereux (MOD); Margaret Senior (University Grants Committee), Henry Parris (Department of Employment), Chris Robson and Philip Bovey (DTI Sols): for affiliations see Memo, Working Party on Employee Inventions, 25 June 1976: IPCD: 41183. All minutes of the Working Party are in IPCD: 41183.

91. TMPDF Council Minutes, 10 September 1976: Bod: B42/F4. 
The starting point presented to the Working Party ${ }^{92}$ was in a Patent Office Note, ${ }^{93}$ which in its final paragraph set out its view of the SAC conclusions from the earlier March meeting: ${ }^{94}$

(1) Subject to paragraph (2), the rights in an invention made by an employee shall lie wholly with the employer where

(i) the invention has resulted from research or development activities which is the primary task of the employee,

(ii) the invention arose out of a general obligation on the part of the employee to further his employer's interests,

(iii) [any other cases].

In all other cases, the rights shall be wholly with the employee.

(2) Where the right lies wholly with the employer, and the employee's contract of service is governed by UK law, the employee shall be entitled to payment by his employer of a fair share of the financial benefit which the employer enjoys from [UK] patents for the invention. In determining such a share, regard shall be had to:-

(i) the nature of the employee's duties and the remuneration he receives from them,

(ii) the extent to which advice, equipment and any other assistance is provided by the employer,

(iii) [any other factors].

There shall be no payments over and above an employee's remuneration for his employment where the employee is paid to engage in research or development work and the invention arises in the course of such work.

It is clear this note set the tone and direction of the Working Party's deliberations. ${ }^{95}$ The group finally reported after meeting six times, ${ }^{96}$ whereupon its conclusions were approved by the Minster ${ }^{97}$ before being referred back to the SAC in September $1976 .{ }^{98}$ It was clear that the SAC had to accept the Working Party Report as a package ${ }^{99}$ and so there was no room to reopen any of the issues at its September meeting. The Report then became central to the development of the policy

92. Edward Armitage (Chair), Working Party Minutes, 1st Meeting, 5 July 1976; in a subsequent meeting it was agreed that the Note was only a framework for discussions: Working Party Minutes, 2nd Meeting, 19 July 1976.

93. Interdepartmental Working Party on Employee Inventions: Note by Patent Office, [17]: IPCD: 41183.

94. It was pointed out later that paragraphs 2(i) and (ii) of the extract above had been based on the Patents (Employees' Inventions) Bill 1965: Working Party Minutes, 6th Meeting, 23 August 1976, p 6.

95. A TMPDF summary of the deliberations is in TMPDF Council Minutes, 10 September 1976: Bod: B42/F4 (IPI 'unashamedly out for what they could get', TUC 'handicapped by a limited knowledge of the subject', Civil Service trying to 'protect their own special position, arising from Crown use').

96. 5 and 19 July, 2, 9, 16 and 23 August 1976. It was felt that the TUC had not really communicated well with the rest of the committee: TMPDF, Council Minutes, 8 October 1976, p 3: Bod: B42/F4.

97. Secretary of State for Trade, Office Minute Number 1211: Patents Bill: Employee Inventions, 14 September 1976: IPCD: 41183; also see Submission: Patents Bill: Employee Inventions, 10 September 1976: IPCD 41183.

98. The report itself was completed around 1 September: see Note, Ron Bowen to Edward Armitage, 1 September 1976: IPCD 41183. The Minutes of the SAC Meeting on 23 September 1976 has not been found in IPO files or elsewhere.

99. TMPDF, Council Minutes, 8 October 1976, p 3: Bod: B42/F4. 
to such an extent that the instructions to Parliamentary Counsel were, for political reasons, to follow the recommendations even if something could be expressed more easily than it had been by the Working Party. ${ }^{100}$ The Report's importance was further emphasized on Second Reading by the Lord Chancellor: ${ }^{101}$

My right honourable friend the Secretary of State for Trade, set up a Working Party which included representatives of industry and the TUC, and they agreed on the outlines of the scheme which is to be found in Clauses 36 to $40 .{ }^{102}$ The scheme has been approved by the Standing Advisory Committee on Patents, which itself includes representatives of the TUC and the CBI ...

Later during Committee, he added: ${ }^{103}$

... I ought to say at the beginning, [the clauses were] drafted to give effect to the agreement that was reached between industry and representatives of employees in a Working Party which was set up last year at the request of the Secretary of State for Trade. It is not easy to achieve the correct balance of interest between employers and employees as regards the ownership of inventions in order to ensure fairness to both. A great deal of discussion took place to achieve the consensus that was arrived at; so I appeal to noble Lords, when they are considering this part of the Bill, to bear in mind that to make two serious alterations to that balance might endanger the whole package ...

This did not mean that the organizations represented at the Working Party had accepted the deal. ${ }^{104}$ While industry bodies, such as the TMPDF, 'reluctantly accepted'105 the compromise, there were companies that individually lobbied against the proposal. ${ }^{106}$ The TUC, while a very active a member of the Working Party, ${ }^{107}$ still lobbied to try to change the settlement, lamenting that the group was set up with only a short time

100. See Patents Bill: Further Instructions Regarding Employees' Invention, 7 October 1976, [7]: BT/103/1820 and also in AM1/2439 ('Instructions to Counsel') (the comment related to the three categories of employee in what is now s 39(1)); see Working Party Report: p. 157.

101. HL Deb, 24 January 1977, Vol 379, col 311-12; something similar was said by the Minister in the Commons: (Stanley) Clinton Davis, HC Deb, 25 May 1977, Vol 932, col 1442. 102. This became the Patents Act 1977, ss 39-43.

103. HL Deb, 24 February 1977, Vol 380, col 400; the fact it was a compromise was also raised by Lord Lyell, HL Deb, 24 February 1977, Vol 380, col 401-2.

104. Even the Lord Chancellor was privately concerned: Letter, Lord Elwyn-Jones (Lord Chancellor) to Edmund Dell, 12 October 1976: IPO File: IPCD 41183 (also in IPCD 39918) where after setting out some key phrases he went on to say: 'My impression is that the courts are to be expected to resolve these problems with little, if any guidance, in the Bill; and yet each point raises questions of a wide and imprecise nature with which your Working Party did not fully grapple.'

105. See Report of the Council, 1 April 1976 to 31 March 1977, p 6: Bod B88/F2; in fact they were, along with the CBI and TMPDF, lobbying opposition MPs to keep to the compromise: TMPDF Council Minutes, 15 April 1977, p 4: Bod: B42/F5.

106. GEC decided to make 'every effort' to remove the provisions: TMPDF Council Minutes, 11 February 1977, p 5: Bod: B42/F5; whereas Procter \& Gamble were to be persuaded from doing the same: TMPDF Council Minutes, 15 April 1977, p 4: Bod: B42/F5.

107. George Doughty: albeit he, like all members, was there in a personal capacity; but see TUC Circular No 243, 6 July 1978 (1977-78): MSS292D/508/4, where he was said to be representing the TUC; also see his article George Doughty 'Workers and Inventions', Transport Review, 27 October 1978 (No 5218), p 8. The Manuscript (with the title 'Trade Unions and the Patents Act 1977') is in MSS292D/508/4. 
to report and employees and small inventors had been generally underrepresented, ${ }^{108}$ leading therefore to the conclusions still falling short of achieving workers' objectives ${ }^{109}$ and leaving the crippling cost of litigating unanswered. ${ }^{110}$

Nevertheless, the role of the Working Party was seen as so central that some in Parliament believed that it had actually drafted clauses; ${ }^{111}$ in fact, this was not the case. While the Working Party proposed clauses, they were so poorly drafted ${ }^{112}$ that they were not even shown to Parliamentary Counsel. In other respects, the inner workings of the Working Party were explored, the Opposition suggesting that the SAC had not supported a statutory scheme, ${ }^{113}$ rather it was just the Working Party. ${ }^{114}$ Although it appears some dissent from the Working Party itself was not public; one member had said privately that it should be made clear that a number - possibly most - of the Party were not in favour of an award scheme at all. ${ }^{115}$ More critically, there was a strong push back in the Standing Committee ${ }^{116}$ against simply accepting, without demurrer, a measure because it was agreed by the Working Party (albeit they commonly referred to it as an agreement between the CBI and TUC). ${ }^{117}$ This led the Minister, Stanley Clinton Davis, to explain further:

What we did was to establish a consultative procedure so that the matter could be investigated in depth by people who had expertise in the subject. That took place and I believe that on a controversial matter - there can be no doubt that rewards for employee-inventors is a controversial matter - it is highly desirable to achieve a solution which is broadly acceptable to all the interests concerned ...

Moreover, the matter did not end there. The compromise agreement was formulated in the standing advisory committees [sic], on which all the interests were represented, and that committee accepted the recommendations of the working party established by the Secretary of State, to which I earlier referred. Therefore, we achieved a very delicate balance, and that was no mean accomplishment. However, to try to achieve the absolutely correct balance between the employers, on the one hand, and the employees on the other ... and so ensure complete fairness to both sides was striving for almost the impossible $\ldots{ }^{118}$

108. Letter, Lionel Murray (General Secretary, TUC) to Edmund Dell (Trade Secretary), 11 May 1977: MSS.292D/508/3 (accepting the Working Party had addressed the underrepresentation somewhat); but Ian Mikardo MP thought it had been packed with employers: Note of Meeting, Secretary of State, Ian Mikardo MP and Douglas Hogg MP, 19 July 1977: IPCD 41343.

109. Speech, George Doughty, 'Trade Union Involvement and Participation in the Practical Working of the New Law', p 7: manuscript in MSS292D/508/4.

110. Ibid, p 9; but see discussion of Patents Act 1977, s 106 at p 151 below.

111. Viscount Eccles, HL Deb, 24 February 1977, Vol 380, col 415.

112. See Annex to Report, $\mathrm{p} 157$.

113. This may refer to the dissent in the March meeting (see pp 131-2) or there may also have been dissent in the meeting in September, but as the minutes are missing it is not possible to be sure.

114. John Nott, HC Deb, 25 May 1977, Vol 932, col 1444-5; also see the suggestion that the Working Party was given a steer: Richard Wainwright, HC Deb, 25 May 1977, Vol 932, col 1470 .

115. Working Party on Employee Inventions: MOD Comments on Chairman's Paper, 20 September 1976, [1]: IPCD 41183.

116. Now called the Public Bill Committee.

117. SC D Deb, 2nd Sitting, 30 June 1977, col 76, 77, 79-81, 82, 102.

118. Clinton Davis, SC D Deb, 2nd Sitting, 30 June 1977, col 94-5. 
He continued, as had the Lord Chancellor, that to reopen one aspect of the package would reopen it all, ${ }^{119}$ and, when earlier he had privately been urged by the TUC to change policy, the Minister reiterated that everyone had signed up to the Working Party recommendations. ${ }^{120}$ Ultimately, the TUC supported 'a good deal' of what was enacted in sections 39 to $43,{ }^{121}$ accepting that the award scheme was a radical change ${ }^{122}$ and one which had caused disquiet amongst patent professionals and industry. ${ }^{123}$ While it would have been unusual at the time, it is still striking that the Working Party's Report has never before been published ${ }^{124}$ when it played such a central role in policy development.

\section{THE LAW THAT WAS PASSED}

The provisions dealing with employee inventions, and awards in particular, were probably the most controversial part of an uncontroversial Act. ${ }^{125}$ There are certain words in sections 39 to 43 which received particular attention both at the time and subsequently. First, what should constitute a 'benefit'; secondly, when does it becomes 'outstanding' and what is the relevance of the size of the employer's undertaking on that assessment; thirdly, when should giving an award be considered 'just'; and fourthly, what is a 'fair share' of the benefit? There was also a debate, and the government even lost a division, on the role that collective agreements might have in displacing the statutory scheme. Finally, there were two things which the government successfully resisted: the ability to contract out of an award, and the allocation of a tribunal to hear claims, although it made some concessions in relation to legal costs. We will look at each of these issues and consider the role of the Working Party Report, beginning with what constitutes a benefit.

\subsection{Benefit}

The Working Party Report proposed that an award for an employee invention owned by the employer should be made in 'exceptional cases', one such case being where it was of 'outstanding value'. ${ }^{126}$ The term 'benefit' was only used in relation to employees assigning their patents to employers at undervalue. ${ }^{127}$ Thus, one case considered benefit, and the other a broader term of 'value'. The Report went further still

119. Ibid, col 95; Brief for Secretary of State, Meeting with Ian Mikardo, 18 July 1977: IPCD 41343 (suggesting even the Bill itself might be in jeopardy).

120. Letter, Clinton Davis (DTI Minister) to Lionel Murray, 21 June 1977: MSS.292D/508/3. Industry took the view that holding the line was an achievement: TMPDF Council Minutes, 11 March 1977, p 3: Bod: B42/F5.

121. Letter, Lionel Murray to Edmund Dell, 11 May 1977: IPCD 41343.

122. Speech George Doughty 'Trade Union Involvement and Participation in the Practical Working of the New Law', p 6: manuscript in MSS292D/508/4.

123. George Doughty 'Trade Unions and the Patents Act 1977', p 5: MSS292D/508/4 (not in Transport Review version).

124. The Report in the Appendix is one of the final versions from the file: IPCD 41183. It is made available under the Open Government Licence for Public Sector Information v 3.0: see $<$ http://www.nationalarchives.gov.uk/doc/open-government-licence/version/3/>. Other copies of the report are in the TMPDF Archives: Bod B23/F1 and B48/F2.

125. See note 3.

126. See pp 155-6.

127. Eventually, Patents Act 1977, s 40(2). 
and said that this value should be the 'realised value' of the patent ${ }^{128}$ (which was meant to mean the actual money the employer received and not what could have been earned by a hypothetical one). ${ }^{129}$ Thus, bringing the broader term 'value' under the narrow 'benefit' umbrella occurred during the drafting phase of the Bill, albeit the drafters' instructions said the assessment should not be limited to 'financial benefit'. ${ }^{130}$

This delineation was also raised by the TUC, it suggested that some inventions had only non-financial benefits, ${ }^{131}$ for example, they said, an invention which improves factory safety could not be assessed in terms of money's worth. ${ }^{132}$ This suggestion is flawed. The infringement of a patent for such an invention would require the loss suffered to be monetized (even if only applying the user principle) ${ }^{133}$ and, likewise, if it was licensed, a fee would have to be calculated. Another example, from the departmental lawyer, ${ }^{134}$ is trickier - what is the benefit when making new weapons for government? ${ }^{135}$ So it became the view that the best solution was to leave the definition of 'benefit' open to interpretation ${ }^{136}$ and this was the approach from the first draft of the Bill, ${ }^{137}$ which did not change before enactment (save in one respect discussed below).

Significantly, the originally enacted s 40(1) required the benefit to come from the patent, and not the invention behind it. ${ }^{138}$ It was an approach which presented problems, as Aldous J later explained in Memco-Med: ${ }^{139}$

The fact that a company only sells a patented product to one customer and therefore its existence depends on sales of that product does not mean that the patent is of any benefit.

I have found it helpful ... to look for indications as to whether [the employer] would have sold any fewer detectors if the patent had not been granted.

128. See p. 156.

129. Working Party Minutes, 3rd Meeting, 2 August 1976, p 4; it was suggested to be the 'actual benefit' by one member: Working Party on Employee Inventions: MOD Comments on Chairman's Paper, 20 September 1976, [12]: IPCD 41183.

130. Patents Bill Further Instruction Regarding Employees' Inventions, [12]: BT 103/1828 (also in AM1/2439); this seems to stem from a discussion of government inventions: see Working Party Minutes, 3rd Meeting, 2 August 1976, p 4.

131. Ian Mikardo, SC D, 3rd Sitting, 5 July 1977, col 119.

132. Ibid, col 119-20.

133. See Roughton, Johnson and Cook, The Modern Law of Patents (4th edn, LexisNexis 2019), [8.118-8.120].

134. Bills usually began with policy officials in the department (such as the Patent Office) instructing their department lawyers what the legislation should do, and this is then developed by the departmental lawyers to become instructions to Parliamentary Counsel, who in turn actually draft the Bill; it was suggested after the Patents Act 1977 had passed that a different procedure should be used for such legislation in future: Edward Armitage, Memorandum Intellectual Property Legislation, November 1977; Letter, Terrance Skemp to John Evans (DTI Sols), 12 August 1977: AM1/2443. Nonetheless, the same procedure was used for the Patents Act 2004 (in respect of which the author was a departmental lawyer).

135. Patents Bill Further Instruction Regarding Employees' Inventions, [12]: BT 103/1828 (also in AM1/2439).

136. Letter, Edmund Dell to Lionel Murray, 9 March 1977: IPCD: 41183.

137. Draft Bill No 15-1, cl 36 and 37: AM1/2431.

138. Memco-Med Ltd's Patent [1992] RPC 403, 407 (PO) and 412-13, Aldous J.

139. Ibid, 417; it had been acknowledged by a member of the Working Party that separating the benefit of the invention from the patent would be difficult: Working Party on Employee Inventions: MOD Comments on Chairman's Paper, 20 September 1976, [12]: IPCD 41183. 
The appropriateness of considering the benefit only from the patent and ignoring the invention was raised in the 2002 Patent Office consultation on what was to become the Patents Act $2004 .{ }^{140}$ General support was given to the idea that awards should be extended to include the benefit from the patented invention ${ }^{141}$ as well as the patent itself. ${ }^{142}$ This change was implemented in the 2004 Act, making the 'benefit' different depending on whether the patent was granted before or after 1 January $2005 ;^{143}$ the benefit comprises only that from the patent itself for those granted before that date (old patents) but the combined benefit from both the patent and the invention for patents granted after that date (new patents).

It became the case that the benefit should be assessed as that which the actual employer ${ }^{144}$ has derived, or may reasonably be expected to derive, ${ }^{145}$ from the invention, the patent or the assignment of either. ${ }^{146}$ The benefit from the patent ${ }^{147}$ (or invention), the Supreme Court has said, means the benefit in the hands of the employer after deduction of any costs to the employer of securing that benefit, ${ }^{148}$ and it includes the time value of money but allows no discount for tax. ${ }^{149}$ It is (as far as possible) assessed after the event based on the actual benefits accrued. ${ }^{150}$ This means that an employer who does little with the invention, even if a fortune could have been made, has accrued no benefit and the employee is entitled to nothing. ${ }^{151}$ The legislation provides that benefit means money

140. Consultation Paper on the Proposed Patents Act (Amendments) Bill (29 November 2002), [76]: <https://webarchive.nationalarchives.gov.uk/20120703125326/http://www.ipo.gov.uk/ patact.pdf $>$ ('Consultation (2002)'), [77].

141. And not extend to unpatented inventions: Consultation on the proposed Patents Act (Amendment) Bill: Summary of Responses and the Government's conclusions (2003) ('Responses to Consultation (2003)'), [104]: <https://webarchive.nationalarchives.gov.uk/ 20120703125325/http://www.ipo.gov.uk/patact-response.pdf>.

142. Responses to Consultation (2003), [104 and 105].

143. Patents Act 2004, s 10(8) and the Patents Act 2004 (Commencement No. 2 and Consequential, etc. and Transitional Provisions) Order 2004 (SI 2004/3205), art 2.

144. Shanks v Unilever [2010] EWCA Civ 1283; [2011] RPC 12, [25]; and [2019] UKSC 45, [31 and 32]; as to a connected person: see Patents Act 1977, s 43(8); in Fellerman v Thorn EMI $(\mathrm{O} / 11 / 96)$ the wrong successor in title was sued and so the claim failed.

145. The word 'derive' might be broader than has yet been stated by the court in relation to patents: see $R$ (on Application of Unison) $v$ Secretary of State for Health [2009] EWHC 3221 (Admin), [50 to 55].

146. Patents Act 1977, s 41(1) (as amended by Patents Act 2004, s 10).

147. Both domestic and foreign: Patents Act 1977, s 43(4); indeed, GEC Avionics [1992] RPC 107,111 was solely concerned with the benefit from the US patent; it is necessary to identify in pleadings the patents from which the benefit is claimed: ibid and British Steel plc [1992] RPC 117,121 . It was questioned by the tribunal, although accepted by the parties, in Fellerman $v$ Electrolux (O/75/98), [5] that unrelated patents could be considered together.

148. Shanks $v$ Unilever Plc [2019] UKSC 45, [35].

149. Ibid, [60-68] and [55-59].

150. Kelly v GE Healthcare [2009] EWHC 181 (Pat), [60(xii)]; also see Frederick Elwyn-Jones (Lord Chancellor), HL Deb, 3 March 1977, Vol 380, col 750.

151. Shanks $v$ Unilever [2009] EWCA Civ 1283, [15-21], where it was argued the assessment should include the 'putative' benefit; the under-exploiting employer was acknowledged as missing from the provisions at the time: Employee Inventors Bill: Additional Comments (MSS.292D/508/3). In the 1980s, the Conservation government considered addressing this issue, but never did: see Intellectual Property Rights and Innovation (1983-4 Cmnd 9117), [5.29-5.31], which proposed that employees should be able to reclaim inventions where their employers refused to exploit it; also see Intellectual Property and Innovation (1985-1986 Cmnd 9712), [4.21-4.31]. 
or money's worth. ${ }^{152}$ In another context, the later term means 'equivalent to money' in the sense of something essentially material, and not an emotional or spiritual reward. ${ }^{153}$ Thus, it appears the Court, in a roundabout way, has interpreted benefit in line with the concept of 'realized value' proposed by the SAC Working Party.

Moving from the abstract to the practical, the assessment of the benefit in the case of an old patent is the amount of money made from the patented invention (the whole benefit) less the money that would have been made had there been no patent (so creating the net benefit). ${ }^{154}$ In the case of licensing fees, this is straightforward: in the absence of the patent no fees would be received; so the benefit is the totality of the fees receipts. ${ }^{155}$ In cases where the employer works the invention itself, the benefit is calculated by assuming the invention is worked, but is unprotected by patents, to estimate how it would have performed and then compare it with the actual profit. ${ }^{156}$

The court has yet to assess the benefit from a new patent, that is the benefit from the invention either alone or in conjunction with the patent. In cases where it was licensed, the benefit would be the same as for the patent alone. While it is possible to license an invention ('know-how'), ${ }^{157}$ the statutory award has a prerequisite that a patent has been granted ${ }^{158}$ and the invention would not be licensed without the patent. In relation to an invention that is worked - such as where a patented product is manufactured and sold - then the benefit would become the whole benefit and not the net benefit (as it is to cover the benefit of both the invention and the patent). This would mean the benefit assessed may be much larger in relation to new patents than it is for old patents. But, once calculated, it must be 'outstanding' and it may be that this threshold is raised accordingly.

In British Steel, other benefits were put forward unsuccessfully: saving royalties on other inventions (in that, if the employee's invention was not used, the employer would have to license a similar system); retention of orders (the invention enabled the employer to meet demand which would otherwise not be met); reduced processing costs; lower levels of waste from production; lower levels of machine breakages or stoppages during production; improved safety; and increased output. ${ }^{159}$ In Drage v Garrison, it was suggested that benefits might also include competitors removing products from the market or settling infringement claims. ${ }^{160}$ Thus, it is possible that the assessment of the benefit might extend beyond those arising from the legal exploitation of the invention, but as yet this has never been successfully established.

\section{2 'Outstanding'}

The gateway to receiving an award is that 'having regard among other things to the size and nature of the employer's undertaking, the invention or the patent for it

152. Patents Act 1977, s 43(7).

153. Gideon's International Service Mark [1991] RPC 141, 142-3; the term is widely used but otherwise seems not to have been defined: see Daniel Greenberg (ed), Stroud's Judicial Dictionary of Words and Phrases (10th edn, Sweet and Maxwell 2016).

154. Kelly v GE Healthcare [2009] EWHC 181 (Pat), [132]; the terms 'whole benefit' and 'net benefit' are the author's.

155. Shanks v Unilever $(\mathrm{O} / 259 / 13)$, [183].

156. Kelly v GE Healthcare [2009] EWHC 181 (Pat), [132].

157. See Tanya Aplin, Lionel Bently, Phillip Johnson and Simon Malynicz, Gurry on Breach of Confidence (2nd edn, Oxford University Press 2012), [8.120-8.147 and 9.17-9.42].

158. Patents Act 1977, s 40(1)(a).

159. British Steel's Patent [1992] RPC 117, 124-6.

160. Drage v Garrison Ltd (O/44/97), $\mathrm{p} 11$. 
(or the combination of both) is of outstanding benefit ${ }^{161}$ to the employer'. ${ }^{162}$ The 'outstanding' threshold was controversial from the start. ${ }^{163}$ The SAC Working Party had set the threshold in the following terms 'an award should be available in exceptional cases. If, for instance, an invention proves to be of outstanding value to the employer', ${ }^{164}$ and this was more or less copied into the Patent Office instructions to departmental solicitors, ${ }^{165}$ then the departmental instructions to Parliamentary Counsel ${ }^{166}$ and then (with one significant change ${ }^{167}$ ) into the first draft of the Bill, ${ }^{168}$ which provided the test as 'the patent is of outstanding benefit to the employer'. Thus, the example of an exceptional case became the only case once it reached the bill. This was probably due to concern from the Lord Chancellor who thought that it might be difficult for the courts to work out 'exceptional cases' without any guidance. ${ }^{169}$ So the Patent Office suggested that 'outstanding benefit' ${ }^{170}$ might be better, albeit the Lord Chancellor still believed privately that even the new term was 'nebulous'. ${ }^{171}$

Notwithstanding their involvement in the SAC Working Party, both the IPI and the TUC pushed back against the 'outstanding' standard. The IPI held a meeting, with Lord Lloyd ${ }^{172}$ in attendance, where it was said that the word 'outstanding' should be removed ${ }^{173}$ because it was narrow and difficult to assess. ${ }^{174}$ This subsequently became the firm position of the TUC, ${ }^{175}$ with an alternative call for the term 'outstanding' to have a specific definition. ${ }^{176}$ Some employers were also uncertain how generously the word outstanding would be interpreted, saying that if it were to apply to one

161. There was some confusion in the Lords over whether it was an outstanding invention or outstanding benefit from the invention: HL Deb, 24 February 1977, Vol 380, col 429; this confusion seems to have also existed at the Patent Office as it was said an award only arises 'where the invention has great merit': Letter, Colin Philpott (PO) to K Leo Killeen, 19 October 1976: IPCD 41183. 162. Patents Act 1977, s 40(1)(b) (emphasis added); it was amended by the Patents Act 2004, s 10. The original version (and the only one which has ever been litigated) only applied to the patent providing such a benefit.

163. The requirement of being 'outstanding' had not been required in the Patent Office Note: see p. 133.

164. See Report, p 156; this suggestion was put by Ron Bowen, Working Party Minutes, 6th Meeting, 23 August 1976, p 2.

165. New Patent Legislation: Employee Inventions, 24 September 1976: IPCD: 41183.

166. Patents Bill Further Instruction Regarding Employees' Inventions, [9]: BT 103/1828 (also in AM1/2439).

167. An earlier internal draft did use 'exceptional circumstances': see AM1/2440.

168. The first draft Bill to include the provisions was Draft No. 15-1, 6 December 1976: AM1/2431.

169. Letter, Lord Elwyn-Jones to Edmund Dell, 12 October 1976: IPCD 41183. It was suggested in a Conference paper by Bruce Cawhra, presented 26-27 September 1977, that an example of such a patent was the float glass patents held by Pilkington: Bod B62/F4; but the origin of the example is not clear.

170. Submission, Ron Bowen to Edmund Dell, 22 October 1976: IPCD 41183.

171. Letter, Lord Elwyn-Jones to Clinton Davis, 4 July 1977: IPCD 41343.

172. This is probably the meeting mentioned in Report of 109th Annual Trades Union Congress (TUC 1977), p 257 (No 375).

173. Minutes of Patent Legislation Committee, 10 January 1977: MSS.292D/508/3.

174. Institute of Patentees and Inventors: Employee Inventors Bill: Additional Comments: MSS.292D/508/3.

175. See for instance, Trade Union Congress: Patent Law Reform, A Discussion Document: MSS.292D/508/3, p 5: Employee Inventors Bill: Additional Comments: MSS.292D/508/3.

176. Letter, George Doughty to Colin Philpott, 4 January 1977, p 1: MSS.292D/508/3. This arose from a concern based on the belief that otherwise it might exclude almost every invention from is scope (p 2). 
or two inventions a year nationally ${ }^{177}$ it would be acceptable, but it applying to thousands would be a serious concern. ${ }^{178}$

During its passage through Parliament other ways of describing 'outstanding' were used: being exceptional, ${ }^{179}$ or being a 'humdinger', ${ }^{180}$ and that it was something more than merely substantial benefit. ${ }^{181}$ Somewhat surprisingly, in a private meeting, the Minister suggested that outstanding just meant 'any benefit out of the ordinary'. ${ }^{182}$ The view of the TUC, that the word 'outstanding' was indefinable, was unsuccessfully pushed by MPs. ${ }^{183}$ As it was put, the difficulty was identifying it quantitatively - is $£ 5000$, $£ 5$ million or $£ 500$ million enough to make it 'outstanding'? ${ }^{184}$ The problem was, as had already been pointed out in the Lords, that few synonyms would have been better not even 'exceptional', which the Working Party had proposed. ${ }^{185}$ Nevertheless, it was stated out the courts had had to cope with 'exceptional cases' in relation to patent term extension under the Patents Act $1949^{186}$ and so either 'outstanding' or 'exceptional' were workable. ${ }^{187}$ Yet the difficulties remained, as Ian Mikardo MP ${ }^{188}$ put it:

if the patent is only of benefit to the employer, the employee ... does not get anything. If it is of significant benefit to the employer, the employee does not get anything. If it is of substantial benefit to the employer, the employee gets nothing. If it is of large benefit to the employer, the employee gets nothing at all. If it is of considerable benefit to the employer, the employee gets nothing. So we must cross some strange frontier between 'significant' and the Holy Grail - 'outstanding'. ${ }^{189}$

The government, largely supported by the Conservative opposition, ${ }^{190}$ remained firm: the choice of the word 'outstanding' was an 'integral part' of the scheme, ${ }^{191}$ neither the words 'important' nor 'significant' was enough. The start point was that employees

177. It did not stop someone trying to set up a special agency (the Employee Inventors Agency) to handle claims: see TMPDF, Council Minutes, 9 November 1979, p 6: Bod B43/F2.

178. Letter, Edmund Page (Westinghouse Brake and Signal) to George Doughty, 15 June 1977, p 2. MSS.292D/508/3. Page did not seem popular at the TUC, being called 'our "old friend"': Letter, George Doughty to Jim Hanna (TUC), June 1977: MSS.292D/508/3; also see Edmund Page, Letters Patents Bill - Employees' Inventions (1977) CIPA Journal 573; TMPDF thought the number of cases would be 'small': TMPDF, Council Minutes, 11 November 1977, p 3: Bod B42/F5.

179. Lord Elwyn-Jones, HL Deb, 24 February 1977, Vol 380, col 411.

180. Ibid.

181. HL Deb, 24 February 1977, Vol 380, col 414.

182. Clinton Davis, Note of Meeting, Secretary of State, Ian Mikardo MP and Douglas Hogg MP, 19 July 1977: IPCD 41343; also see Anthony Miller (PO), Submission to the Minister, 20 July 1977: IPCD 41343.

183. Ian Mikardo, SC D, 2nd Sitting, 30 June 1977, col 112; 3rd Sitting, 5 July 1977, col 115. 184. Lord Brown, HL Deb, 24 February 1977, Vol 380, col 420.

185. Earl of Halsbury, HL Deb, 24 February 1977, Vol 380, col 431.

186. Patents Act 1949, s 23(1) (a ten-year patent extension, rather than one for five years, was permitted in 'exceptional cases').

187. Lord Belstead, HL Deb, 24 February 1977, Vol 380, col 430.

188. He was strongly against the compromise position and put down amendments to radically change it: see TMPDF, Patents Committee Minutes, 22 July 1977, p 2: Bod B23/F1 (TMPDF called these 'wrecking amendments', that is, amendments to change the clause so much it became unacceptable to the government). He was described as supporting some of these amendments with 'demagogic oratory': TMPDF, Council Minutes, 8 July 1977, p 4: Bod B42/F5.

189. Ian Mikardo, SC D, 2nd Sitting, 30 June 1977, col 113.

190. See TMPDF, Council Minutes, 18 February 1977, p 3: Bod: B42/F5.

191. Clinton Davis, SC D, 3rd Sitting, 5 July 1977, col 117; the scheme, including in particular, s 39. 
should not get an additional reward where the pay and conditions already reflect the fact that he or she makes inventions, ${ }^{192}$ leaving statutory awards for when it would be unconscionable for the employer to keep the whole benefit, ${ }^{193}$ or, put another way, when the pay and conditions did not reflect the invention. ${ }^{194}$ The Minister expressed confidence that the courts would be able to work out what this means ${ }^{195}$ but it took a long time for them to even start looking at the issue.

The first case before the Comptroller, ${ }^{196}$ GEC Avionics, treated 'outstanding' to mean more than 'significant' or 'substantial' 197 and as something out of the ordinary which would not normally be expected to arise from the employee's normal duties. ${ }^{198}$ In the next case, British Steel, the tribunal went further, suggesting the word 'outstanding' was a comparative and a superlative. ${ }^{199}$ The first definition from the courts was in Memoco-Med Ltd ${ }^{200}$ where Aldous J did not disagree with these earlier comments and went on to say:

The word 'outstanding' denotes something special and requires the benefit to be more than substantial or good. I believe that it is unwise to try to redefine the word 'outstanding'. Courts will recognise an outstanding benefit when it occurs. ${ }^{201}$

In 2002 when the provisions were being reconsidered ${ }^{202}$ there was, in general, no appetite to change the 'outstanding' requirement; although some respondents suggested repealing the provision altogether. ${ }^{203}$ However, in contrast to 25 years earlier and due to the very changed role of unions during that time, the respondents did not include the TUC, IPI or other representatives of employees; rather they were multinational companies and representatives of patent lawyers. After nothing changed, the next development was Kelly where Floyd J concluded that it was unwise to define the word 'outstanding' although he thought the Act did not require a superlative (in the sense the benefit could not be improved). ${ }^{204}$ In the end, the Supreme Court in Shanks $v$ Unilever $^{205}$ answered the question about what 'outstanding' meant in a very traditional, sensible, but ultimately mundane way:

... [it] is an ordinary English word meaning exceptional or such as to stand out and it refers

here to the benefit (in terms of money or money's worth) of the patent to the employer rather

192. Clinton Davis, SC D, 3rd Sitting, 5 July 1977, col 117; the opposite view was that in such a case the benefit awarded would be very low: Ian Mikardo, SC D, 3rd Sitting, 5 July 1977, col 118. 193. Clinton Davis, SC D, 3rd Sitting, 5 July 1977, col 117.

194. Ibid, col 117.

195. Ibid, col 116.

196. In fact, heard by a delegate - usually a Supervising Examiner - these are now called simply Hearing Officers.

197. But this was not based on any reference to Hansard as it was before Pepper v Hart [1992] AC 593.

198. GEC Avionics Limited's Patent [1992] RPC 107, 115; expressly adopted by the Hearing Officer in Memco-Med Ltd's Patent [1992] RPC 403, 407.

199. Re British Steel's Patent [1992] RPC 117, 122; the conflict between these two was highlighted by Floyd J in Kelly v GE Healthcare [2009] EWHC 181 (Pat), [21].

200. [1992] RPC 403.

201. Memco-Med Ltd's Patent [1992] RPC 403, 414.

202. In the other cases between 1992 and 2002, the earlier case law was just adopted: Drage $v$ Garrison Ltd (O/44/97), pp 6-7; Milner v Dixons (O/164/98), [15]; in Fellerman v Electrolux $(\mathrm{O} / 75 / 98)$ no benefit was particularized so it was never assessed for being outstanding.

203. Responses to Consultation (2003), [96, 98 and 99].

204. Kelly v GE Healthcare [2009] EWHC 181 (Pat), [19 and 21].

205. [2019] UKSC 45, [39]. 
than the degree of inventiveness of the employee. It is, however, both a relative and qualitative term ...

Further, and critically, the Supreme Court held that when assessing whether a patent (or invention) has been of outstanding benefit the court should not simply look at an undertaking's overall profitability or the value of all of its sales. ${ }^{206}$ The profits and sales of products that have nothing to do with the technology which is the subject of the patent may have nothing to do with the commercial success of the patented invention. ${ }^{207}$ Thus, when making the assessment of whether something is outstanding or not there should be some comparison of like with like. In small companies which work in one area of technology it may be that overall profitability is relevant, ${ }^{208}$ but where a company spans a wide range of products then the comparison should be with the benefit from that patent compared to other patents for similar technology. ${ }^{209}$ The requirement for there to be an 'outstanding' benefit turned out to restrict the availability of awards far more than ever envisaged by the Working Party.

\subsection{The size and nature of the employer's undertaking}

The Patents Act 1977 provides that when assessing whether the benefit is outstanding regard has to be had to, among other things, 'the size and nature of the employer's undertaking'. ${ }^{210}$ This concept was not one which was proposed by the Working Party, rather it was introduced during the drafting stage of the Bill ${ }^{211}$ (probably) without specific instructions. ${ }^{212}$ The phrase introduces a point of comparison for the benefit (as otherwise 'outstanding' would have no clear point of reference which would have been an obvious problem). The first time the size of the undertaking was considered it was dismissed in a cursory fashion with the undertaking being taken to be the whole company. ${ }^{213}$ However, in Memco-Med a more nuanced approach was taken in that the employer's undertaking may be the whole or a division of the employer's business. ${ }^{214}$ In 2002, during the Patent Office consultation, it was said that: $:^{215}$

Some argue that this is an unnecessary restriction which may weigh the test too heavily against an employee working for a large company. Arguably, however successful or lucrative a single patent might be, it will never be of 'outstanding' benefit in comparison to the turnover of a successful multi-national company.

206. Shanks v Unilever Plc [2019] UKSC 45, [54].

207. Ibid, [54].

208. See comments regarding Kelly: Shanks v Unilever Plc [2019] UKSC 45, [52].

209. Shanks v Unilever Plc [2019] UKSC 45, [48 and 51].

210. See Patents Act 1977, s 40(1)(b).

211. See Draft Bill 15-2, 9 December 1976, Cl 36, where it was not present, and clause 37 in Draft Bill 15-3, 16 December 1976, where it was: AM1/2431. There were no written instructions to add it, but hand-written annotations in Draft Bill 15-3 suggest the addition of 'amongst other things' so it was probably raised in a telephone call or during a meeting.

212. See generally Phillip Johnson 'Mr Skemp's Preposterous Provision: The Drafting of the Patents Act 1977 and Harmonization in the 1970s' (2015) 5 QMJIP 367.

213. British Steel's Patent [1992] RPC 117, 122; the same approach seems to have been taken in GEC Avionics [1992] RPC 107, 115.

214. Memco-Med Ltd's Patent [1992] RPC 403, 414, Aldous J.

215. Consultation (2002), [76]. 
After the consultation the government agreed "with the view ... that the courts have already suggested the undertaking concerned might, in appropriate circumstances, be a division (rather than the whole) of the employer's business' ${ }^{216}$ and the Explanatory Notes to the Patents Act 2004, despite no relevant amendment being made, stated something similar. ${ }^{217}$ The import of these words was central to Shanks $v$ Unilever, and when it first reached the Court of Appeal in 2010, Jacob LJ said in passing:

I am far from convinced that Parliament meant that inventor/employees of large companies should get less or no compensation for a particular invention compared with what they would get if they had been employed by a small company. It may indeed be the other way round in that a large payment may be too much for a small company to [be] able to afford and that was what Parliament had in mind. ${ }^{218}$

While this may have combined the size of benefit with the fair share, ${ }^{219}$ it came before the so-called 'too big to pay' argument which made it all the way to the Supreme Court. To understand this argument, it is necessary to determine the undertaking which has received the benefit. In Shanks the Hearing Officer all the way to the Court of Appeal took this undertaking to be the entire group (Unilever plc). ${ }^{220}$ Thus, while the profits from the patent were considerable and far in excess of any other income of the same type, it was still necessary to make a broader comparison with the financial position of the group as a whole. ${ }^{221}$ Even the caveat of the Court of Appeal that the benefit relative to the size of the business was only a factor in the determination ${ }^{22}$ meant little in practice as Briggs LJ candidly said:

It may be going too far to say that Unilever was simply 'too big to pay', but there is no escaping the fact that Professor Shanks might well have succeeded had his employer had a much smaller undertaking than did Unilever. ${ }^{223}$

But this approach would be entirely contrary to the origins of the provision - a Working Party with Union and employee representation set up to balance the interests of employees and employers - and it is inconceivable the TUC or even the CBI would have supported a law which means that smaller companies are more likely to have to award compensation that larger ones. ${ }^{224}$ The Supreme Court, however, moved away from this approach, holding that the benefit from the patent should be divorced from overall sales and profitability.

Thus, it held, that the importance of the size of the undertaking is not its turnover or annual profits but a series of more nuanced things: the benefit may be more than would normally have been expected to arise from the duties for which the employee was paid;

216. Responses of Consultation (2003), [103]; see Memco-Med Ltd's Patent [1992] RPC 403, 414.

217. Explanatory Notes to Patents Act 2004, [62].

218. Unilever Plc $v$ Shanks [2010] EWCA Civ 1283, [17].

219. Shanks $v$ Unilever Plc [2014] EWHC 1647 (Pat), [69].

220. Shanks v Unilever (O/259/13), [196]; [2017] EWCA Civ 2, [34].

221. Shanks v Unilever Plc [2017] EWCA Civ 2, [60]; see also Jeremy Phillips and Michael Hoolahan, Employees' Inventions in the United Kingdom: Law and Practice (ESC Publishing 1982), pp 62-3.

222. Shanks v Unilever Plc [2017] EWCA Civ 2, [61-62].

223. Shanks $v$ Unilever Plc [2017] EWCA Civ 2, [68].

224. See Roughton, Johnson and Cook, The Modern Law of Patents (4th edn, LexisNexis 2019), [9.98-9.99]. 
it may have been arrived at without any risk to the business; it may represent an extraordinarily high rate of return; or it may have been the opportunity to develop a new line of business or to engage in unforeseen licensing opportunities. ${ }^{225}$ Also, a large undertaking may be able to exert greater leverage than a smaller undertaking when negotiating licence fees; another thing of note is whether the company is in a position to spend substantial sums on litigation to enforce its rights; and, finally, a large undertaking might be able to harness its goodwill and sales force in a way that a smaller undertaking could not. ${ }^{226}$ While this approach was not necessarily what the drafter of s 40 had intended by including these words (the approach of the Court of Appeal being much closer) the Supreme Court's judgment is in keeping with the concerns and the report of the Working Party. This takes us to whether an award is 'just'.

\subsection{Just that the employee should be awarded compensation}

The idea that an award should only be made where it is 'just' was in the first draft of the compensation provision, ${ }^{227}$ having been added by Parliamentary Counsel. It was discussed little in Parliament, indeed, when an invention or patent has crossed the high hurdle of providing an outstanding benefit it is difficult to see where it might stumble for being unjust to award it, ${ }^{228}$ particularly where the employee is only entitled to a 'fair' share of the benefit which would be tailored to make any award just (after all, a fair share may be nothing at all). Indeed, in the two cases that have got as far as considering whether making an award is just, no factors have been considered as sufficient to hamper it, and, in particular, none of the following: long delays in bringing a claim; waiting until after the employment had ended; zero risk being carried by the employee; ${ }^{229}$ significant benefits already having been given to the employee; and the fact that one employee might get an award and another not. ${ }^{230}$ In short, the need for it to be 'just' generally equates to what the Working Party required an employee be given, namely a 'fair share' of the benefit.

\subsection{The employee gets a fair share}

The Working Party's proposal that an employee should get a 'fair share' of the benefit $^{231}$ was thought by the Lord Chancellor to be difficult for the courts to determine without any guidance. ${ }^{232}$ So the original bill proposed ${ }^{233}$ that when assessing the fair share 'all the circumstances' should be taken into account, and it specified two things taken from the Working Party Report that evolved to became paragraphs (a) and

225. Shanks $v$ Unilever Plc [2019] UKSC 45, [51].

226. Ibid, [53].

227. Draft Bill 15-1, 6 December 1976, Cl 36(1): AM1/2431.

228. In Kelly v GE Healthcare [2009] EWHC 181 (Pat), Floyd J left it open, [41]; it was conceded in Shanks v Unilever (O/259/13), [171].

229. So no need for the employee to prove a loss: Kelly $v$ GE Healthcare [2009] EWHC 181 (Pat), [60(xi)].

230. Kelly v GE Healthcare [2009] EWHC 181 (Pat), [154-160].

231. See $\mathrm{p} 156$.

232. Letter, Lord Elwyn-Jones to Edmund Dell, The Patents Bill, 12 October 1976: IPCD 41183.

233. Patents Bill (As Introduced) (1976-77 HL Papers 28), Vol 3. 
(d) in section 41(4) of the 1977 Act, which in the Lords Committee was extended further: ${ }^{234}$

... take the following matters into account, that is to say-

(a) the nature of the employee's duties, his remuneration and the other advantages he derives or has derived from his employment or has derived in relation to the invention under this Act;

(b) the effort and skill which the employee has devoted to making the invention;

(c) the effort and skill which any other person has devoted to making the invention jointly with the employee concerned, and the advice and other assistance contributed by any other employee who is not a joint inventor of the invention; and

(d) the contribution made by the employer to the making, developing and working of the invention by the provision of advice, facilities and other assistance, by the provision of opportunities and by his managerial and commercial skill and activities.

In the abstract it is impossible to disagree with the idea that an employee should get a 'fair share' of the benefit. The real question is what is fair? ${ }^{235}$ The courts have considered section 41(4)(a) to be directed to whether the employee has already received some recognition for making an invention of outstanding benefit (such as promotions, international acclaim or better bargaining position for a new job). ${ }^{236}$ The assessment of effort and skill, for the purposes of paragraph (b), is likely to be very fact dependent although 'monumental' efforts are clearly enough ${ }^{237}$ but the duration of the labour should not be determinative. ${ }^{238}$ Paragraph (c) includes only the efforts of non-inventor employees and it appears that it is necessary to identify a particular person ${ }^{239}$ or persons. The broader research and business ${ }^{240}$ environments are to be considered under paragraph (d). This paragraph also requires weighing up the following in favour of the employee: the cost of the research and development to the profits received and the degree of thought and creativity employed; ${ }^{241}$ and in favour of the employer: whether the employer presented the opportunities, the further development and work which occurred in getting the product to market, the development of markets for the product, and critically the acceptance of the risk. ${ }^{242}$ The Working Party's limited guidance on what amounted to a fair share, adopted and expanded in the Act, could be entirely set aside if there was a collective agreement.

234. Inserted in Committee in the Lords: see HL Deb, 3 March 1977, Vol 380, col 751; while the proposal in the Patents (Employees' Inventions) Bill 1965, cl 1(3) was similar in effect, the wording was different and so there does not seem to be a direct link.

235. Employers were advised by industry bodies to take a liberal attitude: Report 'Employee Inventions' (C.6/78), p 4: Bod: B70/F1; a slightly shorter version of the report is at: Monthly Report, March 1978, Pt 1: Bod B62/F4.

236. Kelly v GE Healthcare [2009] EWHC 181 (Pat), [178-179]; Shanks got none: Shanks v Unilever (O/259/13), [229].

237. Kelly v GE Healthcare [2009] EWHC 181 (Pat), [182].

238. Shanks $v$ Unilever $(\mathrm{O} / 259 / 13),[232]$.

239. Kelly v GE Healthcare [2009] EWHC 181 (Pat), [185].

240. Including marketing: Lord Elwyn-Jones, HL Deb, 5 May 1977, Vol 382, col 1187-8; this was also said in relation to the Patents Act 2004: Lord Sainsbury, HL Deb, 8 March 2004, Vol 658, col GC358 and 363.

241. Kelly v GE Healthcare [2009] EWHC 181 (Pat), [188].

242. Kelly v GE Healthcare [2009] EWHC 181 (Pat), [189]. 


\subsection{Collective agreements}

The Working Party strongly rejected any suggestion that individuals should be able to agree their own terms in place of the statutory rules. ${ }^{243}$ On the other hand, and unsurprisingly considering the strong trade union activism in the Working Party, the Report concluded that a collective agreement might provide a better deal for an employee and so it should be able to replace the rules in the statue. It was originally proposed that the provision on collective agreements would apply to an employee of the same type whether he or she was actually a member of the union. ${ }^{244}$ This position was thought unfair by some $^{245}$ and while the government initially held the line ${ }^{246}$ saying Unions would not agree less advantageous terms ${ }^{247}$ it eventually lost the division ${ }^{248}$ and an amendment was made. ${ }^{249}$ The strength of the unions meant the prospective role of collective agreements was ranked incredibly high, with the Lord Chancellor, and so the government, expressing the view that most of the employee award disputes would be resolved under collective agreements (and so the statutory scheme would not usually apply). ${ }^{250}$

A degree of chatter after the provision was enacted indicates that some unions were thinking of undermining the award scheme entirely by adopting collective agreements that provided for the benefit of awards to be shared amongst all workers in a plant and not given to the inventor alone. ${ }^{251}$ However, in the end, there may have been very few (if any) collective agreements. ${ }^{252}$ For example, the National Coal Board felt there was little point in devising a collective agreement as they already had their own Award Scheme and, furthermore, the Act was limited to patents filed after 1 June $1978,{ }^{253}$ meaning it would take five years before any invention had been shown to be of outstanding benefit. ${ }^{254}$

243. See p 157.

244. And also to directors and others: see Working Party Minutes, 4th Meeting, 9 August 1976, p 3.

245. Lord Belstead, HL Deb, 24 February 1977, Vol 380, col 434-5; 5 May 1977, Vol 382, col 1164-5 (and it would encourage closed shops).

246. It was apparently the case that collective agreements binding non-union members were quite common: see Letter, Ron Bowen to Roland Widdows (LCD), 12 April 1977: IPCD 41279. 247. See Lord Elwyn-Jones, HL Deb, 5 May 1977, Vol 382, col 1162-3; the same thing was said by the TUC in the Working Party: Working Party Minutes, 4th Meeting, 9 August 1976, p 3.

248. HL Deb, 5 May 1977, Vol 382, col 1167.

249. Drafting amendments were made to tidy it up subsequently: HL Deb, 17 May 1977, vol 383, col 570 (Amendment 15A).

250. See extract of note in Letter, Lord Lloyd to Jim Hana (TUC), 8 June 1977: MSS.292D/508/3. 251. See Speech, George Doughty 'Trade Union Involvement and Participation in the Practical Working of the New Law', p 15: manuscript in MSS292D/508/4, where he says this would be the wrong approach.

252. There appeared to be have been none in 1977: see 'New Statutory Rights for Employee Inventions' (October 1977) 161 Industrial Relations Review and Report 2 at 5; it is suggested by Paul Cole and Richard Davis (eds), CIPA: Guide to the Patents Act 1977 (9th edn, Sweet and Maxwell 2020), [40.16] that there were examples in Keith Hodkinson 'Employee Inventions and Designs' (1986) 7 Company Lawyer 146 (Pt 1) and 183 (Pt 2). In fact, this is incorrect; Hodkinson included no real-world examples.

253. Patents Act 1977, s 43(1); Patents Act 1977 (Commencement No 2) Order 1978 (SI 1978/586) (C. 14).

254. Letter, George Shephard (Coal Board) to Lawrence Daly (National Union of Miners), 7 September 1978: MSS292D/508/4; a handwritten note from George Doughty suggests the Board's conclusion was not in accordance with TUC thinking. 
The last hurrah for representative involvement was a proposed amendment to the Patents Bill 2004 which would require consultations with employer ${ }^{255}$ representa- $^{-}$ tives before a claim was started. This was rejected on the grounds it would happen anyway as a compensation claim would only be started once relations had broken down. ${ }^{256}$ So it appears that the recommendation by the Working Party, which was taken up by the government, to encourage collective agreements has had little effect in practice, unlike the strict rule against contracting out.

\subsection{Contracting out}

The one relevant Banks Committee recommendation accepted by the government was a rule prohibiting a contract diminishing employees' rights in an invention. ${ }^{257}$ This meant that any suggestion that employees could individually contract out the award system was opposed by the government and, to defend its position, it reverted to the Working Party's recommendations. ${ }^{258}$ Its rationale to resist was that the benefit from an invention could not be known in advance and an employee might agree to receive less than they are entitled to under the scheme. ${ }^{259}$ Accordingly, voluntary award schemes outside collective agreements (notwithstanding Banks recommending them) ${ }^{260}$ were seen as irrelevant. ${ }^{261}$ To counter, it was said employees might want to settle the claim for some money now rather than possibly more later; ${ }^{262}$ further, or alternatively, the relevant employee might have long left the firm or died before the benefit becomes 'outstanding'. ${ }^{263}$ But the compulsory nature of the scheme was central to the package $\mathrm{e}^{264}$ and so the Banks recommendation was enacted despite the stout resistance. ${ }^{265}$ What is strange about this conflict is the restriction only ever applied to contracts made before the invention was devised. ${ }^{266}$ It did not expressly restrict out-of-court settlements of compensation claims ${ }^{267}$ or agreements to get something now rather than more later; however, whether a contractual settlement which is significantly below a statutory award would be upheld by the

255. Not employee representatives (eg unions), showing the change of emphasis and lobbying power over the previous 30 years.

256. See debate on Amendment 6 of Patents Bill: HL Deb, 8 March 2004, Vol 658, col 356-60.

257. Banks Report, [469] (albeit it was referring to common law rights in the invention and not a new statutory code).

258. Lord Elwyn-Jones, HL Deb, 5 May 1977, Vol 382, col 1178-9.

259. Lord Elwyn-Jones, HL Deb, 24 February 1977, Vol 380, col 439-40; HL Deb, 5 May 1977, Vol 382, col 1170-1.

260. Lord Elwyn-Jones, HL Deb, 24 February 1977, Vol 380, col 443; Lord Belstead, HL Deb, 5 May 1977, Vol 382, col 1174.

261. Albeit Lord Belstead spoke in favour of allowing voluntary schemes in place: HL Deb, 24 February 1977, Vol 380, col 441-2; HL Deb, 5 May 1977, Vol 382, col 1173-4.

262. Lord Nelson, HL Deb, 5 May 1977, Vol 382, col 1169-70.

263. Lord Belstead, HL Deb, 5 May 1977, Vol 382, col 1172; Lord Lyell, HL Deb, 5 May 1977, Vol 382, col 1777-8.

264. Lord Elwyn-Jones, HL Deb, 5 May 1977, Vol 382, col 1179.

265. Patents Act 1977, s 42.

266. See Draft Bill 15-1, 6 December 1976, Cl 38(2): AM1/2431.

267. Which has indeed happened see: Paul Cole and Richard Davis (eds), CIPA: Guide to the Patents Act 1977 (9th edn, Sweet and Maxwell 2020), [40.19]. 
courts was, and is, uncertain. ${ }^{268}$ Of course, and in any event, a voluntary scheme or any ex gratia payments ${ }^{269}$ will be taken into account when assessing whether the employee received a fair share. ${ }^{270}$

\subsection{Tribunals}

One of the most contentious issues within the already controversial issue of employee inventions was by whom any compensation claims should be heard. The TUC argued in the Working Party that as it was an employment dispute it should be heard before an Industrial Tribunal, ${ }^{271}$ or, alternatively, a new body with a legal chairman and one employer and one employee representative. ${ }^{272}$ The idea of a special body initially received some support from the Working Party ${ }^{273}$ but it ebbed away. The Patent Office was sceptical about a new tribunal without the demand being known ${ }^{274}$ and the Bar representative was against creating any tribunal which would restrict the right to go to court (suggesting that a choice between the court and the Comptroller was satisfactory). ${ }^{275}$ At one point a partial agreement in the Working Party was reached with the ownership question being determined by the court or Comptroller and the quantum of any award by an assessor. ${ }^{276}$ Ultimately, even this was resisted by the government, and the TUC eventually accepted that voluntary tribunals at 'factory' level would be sufficient to enable most disputes to be settled ${ }^{277}$ and so this became the position of the group. ${ }^{278}$

Accordingly, the Working Party Report proposed that compensation claims should be heard before the court or the Comptroller (the enacted outcome), with rejected disputes being heard by Industrial Tribunals, albeit leaving the possibility of the dispute being resolved by arbitration. ${ }^{279}$ The Bill as introduced allowed claims only before the

268. Report 'Employee Inventions' (C.6/78), pp 3-4: Bod: B70/F1; a slightly shorter version of the report is at: Monthly Report, March 1978, Pt 1, p 2: Bod B62/F4; apparently conflicting Counsel's opinions had been obtained: TMPDF, Council Minutes, 10 February 1978, p 3: Bod: B42/F5.

269. Kelly v GE Healthcare [2009] EWHC 181 (Pat).

270. See Patents Act 1977, s 41.

271. See Letter, Henry Parris to Chris Gadd (PO), July 1976: IPCD 41183; this would have been in accord with the recommendations of the Donavan Committee, Royal Commission of Trade Unions and Employers' Associations (1968 Cmnd 3623), [527-573 and 1062] which said all disputes between employers and employees should be heard by Industrial Tribunals.

272. See Working Party Minutes, 4th Meeting, 9 August 1976, p 4; Working Party Minutes, 5th Meeting, 16 August 1976, p 4; it was questioned whether CBI or TUC representatives would know much about patent law: James Fergusson (Assistant Comptroller), Memorandum: Employment Inventions, 19 August 1976: IPCD 41183; the Lord Chancellor's Department was similarity unsure of the benefit of lay members: Letter, Michael Collon (LCD) to Anthony Miller, 19 August 1976: IPCD 41183.

273. Working Party Minutes, 4th Meeting, 9 August 1976, p 4.

274. Ron Bowen, Working Party Minutes, 5th Meeting, 16 August 1976, p 4.

275. Working Party Minutes, 5th Meeting, 16 August 1976, pp 4-5. This reflected a general opposition to any lay assessors in the court from the Law Society and Bar Council: TMPDF, Council Minutes, 11 July 1975: Bod B42/F3.

276. Working Party Minutes, 6th Meeting, 23 August 1976, p 4.

277. Working Party Minutes, 5th Meeting, 16 August 1976, pp 4 and 5.

278. Working Party Minutes, 6th Meeting, 23 August 1976, p 6.

279. The Bill never precluded voluntary arbitration: Note, Letter, Lord Lloyd to Lord ElwynJones, 13 January 1977: AM1/2441. 
Comptroller, ${ }^{280}$ but quickly the government took the view that employees, as claimants, should also be able to bring the claim before the court (as they selected the forum), ${ }^{281}$ thereby reverting to the recommendation of the Working Party. Yet many interests thought this did not go far enough. The TUC maintained the view that the Comptroller should not make employee awards absent the agreement of the parties, ${ }^{282}$ because there was a need to have the involvement of employee experts. ${ }^{283}$ A positive example, repeatedly cited, was setting up something similar to the former Royal Commission on Awards to Inventors ${ }^{284}$ with a 'broad brush' approach (to contrast with the approach of the court or Comptroller) ${ }^{285}$ Critically, the Patent Judges were against a special tribunal, ${ }^{286}$ and this probably reinforced the government's position against it.

Once before Parliament, in line with the TUC's position, ${ }^{287}$ there was a push to create an 'assessment panel' to determine the size of the award with the Comptroller (or court) only considering legal questions. ${ }^{288}$ The thinking was that experts in industrial relations would be better placed than the Comptroller to assess compensation expeditiously. ${ }^{289}$ This was countered by highlighting the problems caused by the finality of the Patent Appeal Tribunal ${ }^{290}$ decisions, which had led to numerous judicial reviews and eventually to the creation of a right to appeal. ${ }^{291}$ Ultimately, the government took the Working Party line that tribunals set up at factory level by agreement between the employer and employee ought to be encouraged ${ }^{292}$ but then going on to explain that a special statutory tribunal would be expensive ${ }^{293}$ and difficult to staff (the expertise being very limited), while it would be hard to find independent members in the same area of commercial technology. ${ }^{294}$ The government did propose ${ }^{295}$ and enact a solution

280. Patents Bill (As Introduced) (1976-7 HL Papers 28), Cl 37(1).

281. Lord Elwyn-Jones, HL Deb, 24 February 1977, Vol 380, col 421.

282. Minutes of Patent Legislation Committee,10 January 1977: MSS.292D/508/3; see for instance, Trade Union Congress: Patent Law Reform, A Discussion Document, p 5: MSS.292D/508/3; this seems to have been the outcome of the meeting between the IPI and the TUC: Letter, A Leonard Cotterell to Lord Lloyd, 28 April 1977: MSS.292D/508/3.

283. TUC Reaction: MSS.292D/508/3.

284. See Letter, Edmund Page to George Doughty, 15 June 1977: MSS.292D/508/3: Lord Lloyd, HL Deb, 24 February 1977, Vol 380, col 422 and 426, 427; HL Deb, 5 May 1977, Vol 382, col 1157; Richard Wainwright, SC D, 3rd Sitting, 5 July 1977, col 122; as to the actual procedures see Royal Commission on Awards to Inventors, Use of Inventions and Designs by Government Departments: Compendium of the Principles and Procedures (HMSO 1957).

285. Letter, Edmund Page to Derek Cadman (PO), 20 June 1977: MSS.292D/508/3.

286. See Letter, Lord Lloyd to Jim Hanna, 23 March 1977: MSS.292D/508/3.

287. See Lord Lloyd, HL Deb, 5 May 1977, Vol 382, col 1156.

288. Ibid, col 1159-60; Richard Wainwright, SC Deb, 3rd Sitting, 5 July 1977, c 121-2.

289. Richard Wainwright, SC Deb, 3rd Sitting, 5 July 1977, c 122; Lord Lloyd, HL Deb, 5 May 1977, Vol 382, col 1152.

290. For a brief history see Roughton, Johnson and Cook, Modern Law of Patents (4th edn, LexisNexis 2019), [25.62-25.63].

291. Courts Act 1971, s 46; see Lord Elwyn-Jones, HL Deb, 5 May 1977, Vol 382, col 1158. 292. Lord Elwyn-Jones, HL Deb, 24 February 1977, Vol 380, col 423 and 424.

293. Lord Elwyn-Jones, HL Deb, 3 March 1977, Vol 380, col 1154; Clinton Davis, SC D, 3rd Sitting, 5 July 1977, col 124.

294. Lord Elwyn-Jones, HL Deb, 24 February 1977, Vol 380, col 424 and 3 March 1977, col 1154.

295. Letter, Clinton David to Lionel Murray, 25 May 1977: MSS.292D/508/3. 
of sorts, ${ }^{296}$ with a rule ${ }^{297}$ to allow advisors to be appointed to assist the Comptroller. ${ }^{298}$ This was not felt to have gone far enough by some ${ }^{299}$ but was eventually accepted by the Unions. ${ }^{300}$ Accordingly, even where resistance was strongest, the government held the line adopted by the Working Party in keeping disputes away from any special tribunal, but it did make concessions in relation to the related issue of legal costs.

\subsubsection{Costs}

One reason for proposing a special tribunal was the concern that employees would struggle to pay the legal costs arising from a compensation claim. Initially, there were amendments proposed by Lord Lloyd that stipulated that the employee should face no order for adverse costs. ${ }^{301}$ These were resisted on the grounds that costs before the Comptroller were on a moderate scale and it was necessary to prevent vexatious claims. ${ }^{302}$ But when a similar amendment was proposed in the Standing Committee in the Commons the Minister agreed to consider the matter further. ${ }^{303}$ In fact, the Minister had already shared his concerns with the Lord Chancellor that high costs would deter applications and sought his permission to do something. ${ }^{304}$ This led to a new clause being added which enabled the court, when making an order for costs, to consider the financial position of the parties. This clause was warmly received and became section 106 of the Patents Act $1977 .{ }^{305}$ To date no court has ever considered the provision. ${ }^{306}$

\section{FINAL THOUGHTS}

Employee inventions were a critical and politically sensitive issue in 1977 and, like so often, to mitigate any fall-out it was pushed off to a specially constituted committee: the Working Party on Employee Inventions. Its Report became central to justifying the government's policy before Parliament and it even developed a quasi-mythical status despite being unpublished and the Working Party's precise conclusions not being widely known. In simple terms, the Report represented a compromise between the unions and employers groups. Yet any suggestion that in a little over four decades

296. Following from a proposal by Lord Lloyd: HL Deb, 5 May 1977, Vol 380, col 1180-82. 297. Patents Act 1977, s 123(2)(g) and (5) was added in Standing Committee: SC Deb, 4th Sitting, 5 July 1977, col 194-5, Amendments 194 and 195 (made without debate; albeit some warm comments were made in the Lords: HL Deb, 27 July 1977, Vol 386, col 1083-5). This led to Patents Rules 1978 (SI 1978/216), r 109 (now Patents Rules 2007, r 102 (SI 2007/ 3291)); Patents Act 1977, s 123(5) was repealed by the Patents Act 2004, Sch 2, para 26(4).

298. Letter, Edmund Page to George Doughty, 15 June 1977: MSS.292D/508/3.

299. Letter, Edmund Page to Derek Cadman, 20 June 1977: MSS.292D/508/3.

300. Letter, Lionel Murray to Clinton Davis, 2 June 1977: MSS.292D/508/3; Lord Lloyd, however, was not sure it was enough: Letter, Lord Lloyd to Jim Hana (TUC), 8 June 1977: MSS.292D/508/3.

301. Amendment 188: HL Deb, 24 February 1977, Vol 380, col 446-8; a more moderate version was proposed by him later, and rejected: HL Deb, 5 May 1977, Vol 382, col 1180-82.

302. Lord Elwyn-Jones, HL Deb, 24 February 1977, Vol 380, col 447.

303. Amendment 64: SC D, 2nd Sitting, 30 June 1977, col 128-36.

304. Letter, Clinton Davis to Lord Elwyn-Jones, 30 June 1977: IPCD 41343.

305. HC Deb, 22 July 1977, Vol 935, col 2060-62; HL Deb, 27 July 1977, Vol 386, col 1078-80.

306. It was broadened beyond employment compensation claims by Patents Act 2004, s 14. 
there would be only eight claims under the scheme and only two awards made would have been be greeted with disbelief by anyone involved in the Working Party. It may be that the Report set out the right balance and so the effect of the statutory scheme was to change employers' internal award schemes for inventions, making claims unnecessary. But in the handful of cases that have been heard by the Comptroller or court, the outcome has rarely reflected the balance which had been struck in the Working Party and which was lauded in Parliament. Now, however, the Supreme Court's decision in Shanks appears to have moved the law closer to what was envisioned by the Working Party, but even if the number of claims for compensation now increase, it is probable that awards will still be confined to the very rare 'hard cases'. Just what the Working Party agreed. 


\section{APPENDIX: THE REPORT OF THE SAC WORKING PARTY}

SAC/P 132

Inventions made by employees

Report by the Chairman of the Working Party

$\underline{\text { Introduction }}$

1. Following further consideration of views expressed at the SAC meeting on employee inventions reported in SAC/M29, it was decided to set up a Working Party with a view, if possible, to defining a generally acceptable scheme that could be embodied in the projected Patents Bill. The Working Party had the following membership:-

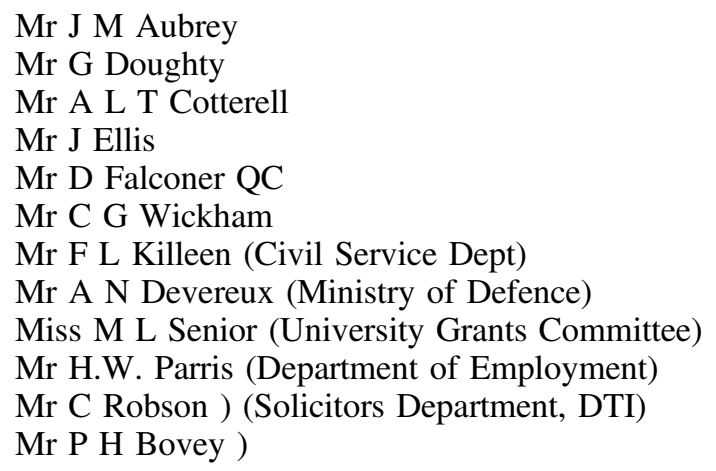

Patent Office staff also attended. The Working Party held 6 meetings, of which the first three were chaired by the Comptroller. I chaired the last three meetings and, since a consensus emerged at the last meeting on the main ingredients of a statutory scheme, I agreed to submit the results of the Working Party's efforts for the approval of the Standing Advisory Committee.

The scheme in broad outline

2. In accordance with views expressed by the SAC, the proposed statutory scheme is limited in its scope to patented inventions. It is also limited in its effect to inventions made by employees who are mainly employed in the United Kingdom; having regard to Article 60 of the European Patent Convention, this ensures that the same unique solution is adopted as for European patents.

3. The scheme first of all defines the cases in which the right to a patent is vested in the employer. Normally no award would be payable to the employee in these cases. In all other cases, the invention is to belong to the employee but if, following negotiations, the employer takes rights in the invention, the employee is to have a right to an award. The scheme also deals with the size of the award; it is to amount to a fair share of the value derived by the employer from any patent that he may acquire in respect of the invention. Finally, so far as concerns the award, operation of the statutory scheme may be ousted by payment made under the terms of a collective agreement.

4. For convenience, a draft embodying the main features of the proposed statutory scheme is annexed. It must be emphasised that this is not intended to be a legal text 
such as might be found in the projected Patents Bill. Moreover, the draft does not cover the following:-

(a) the concurrent jurisdiction of the Court and Comptroller to resolve employer-employee disputes about inventions made by employees, as agreed by the Working Party;

(b) the Banks Committee's recommendation that employees' common law rights may not be reduced by their contracts of employment; this has already been accepted by the government.

Inventions which are to be the exclusive property of the employer

5. Accepting the view that inventions made by employees should belong exclusively either to the employer or to the employee, the Working Party attempted to define the boundary line. As to this, two broad alternatives were open; the matter could be left to the common law or regulated by statute in accordance with defined criteria. The first approach was ruled out by those who felt that the position of employee inventors needed to be improved. They did not consider that the common law was sufficiently clear and straightforward and in touch with modern realities, based as it is on the master and servant approach. Although other members did not share this view and in particular considered that a move away from the common law would result in some loss of flexibility, the Working Party set out to specify the criteria for identifying those inventions made by employees which should belong to the employer.

6. As regards this, the Working Party reached agreement on three categories, as follows:-

(i) Inventions which arise from activity within the scope of the employee's normal duties.

An obvious example is an invention which arises from research on development work for which the employee inventor was specifically engaged. However, the Working Party does not consider that, to satisfy this criteria, the employee must necessarily be employed in research or development nor that inventive activity must be his primary task. The essential point is that the tasks for which the employee is engaged and is being paid are of such a nature that it is possible that an invention may result from performance of these tasks.

(ii) Inventions which arise from a special assignment outside the scope of the employee's normal duties.

Although his normal duties may be such that an invention resulting from their performance would not satisfy criteria (i) above, the employee may be given a special task which may involve innovation. Any invention resulting from this is to belong to the employer. An example within this category is Adamson v Kenworthy (49 RPC 57) where a draughtsman was given a problem to solve in a field of activity on which he was not normally engaged.

(iii) Inventions made by an employee who has a general obligation to further the interests of his employer's business.

The intention here is to cover inventions which, while not satisfying criteria (i) and (ii) above, are made by an employee in such circumstances that it would be inconsistent with the good faith, which ought properly to be inferred or implied as an obligation arising from the employee's 
contract of employment, for the invention not to belong to his employer. This criteria may be expected to apply to inventions devised by employees in senior management; in any particular case, the terms of employment, the nature of the invention and its relation to the employer's business will be relevant factors to be considered.

Inventions which are to be the exclusive property of employees

7. The Working Party also closely considered the question of ownership of inventions made by employees but which did not satisfy any of the above criteria. These are inventions made as a result of the employee's own initiative; they arise from some activity for which the employer has not engaged the employee and is not paying him. An invention within this broad category may have no connection with the employer's business. However, in many cases, the invention will have such a connection. It may, for instance, result in a new product of the kind which it is the employer's business to sell or a new method or process which, in the hands of a competiter [sic], could damage the employer's business. Moreover, the invention may only have been devised by the employee as a result of his or his colleagues' experience in the employer's business or knowledge of earlier efforts or trade secrets.

8. There was general agreement in the Working Party that ownership of the inventions in this broad category should rest with the employee. However, some members advocated that, if such an invention related to the business of his employer, the employer should have a statutory right to claim ownership. This proposition was mainly argued by those representing the desires of employee inventors and on the ground that such a right was very much in the interests of the employers. On the other hand, it was pointed out that to give a statutory right to the employer would effectively deny the full rights of ownership which, as generally agreed, should, in the cases in question, be vested in the employee. The view was also expressed that a statutory right of this nature was unnecessary, because in most cases the employer would be able to negotiate satisfactorily with the employee for such rights in the invention as he wished. It was also pointed out that, if employers were to be given a statutory right to claim inventions of this kind, there would have to be a statutory machinery for notifying inventions and the acceptance or refusal of rights in them. Those who contemplated the matter from the management angle were unanimous in their desire to avoid the practical difficulties and administrative burden that this would inevitably create.

9. In the result, the Working Party did not accept the suggestion that the employer should have a statutory right to claim inventions which are made by his employees and do not come within the criteria (i) to (iii) mentioned above.

\section{Awards to employee inventors}

10. The Working Party was unanimous that employees who make inventions within criteria (i) to (iii) should not normally be entitled to any reward for their efforts over and above the remuneration they receive under their terms of employment. In general, these employees are doing no more than is expected of them and to confer special treatment on them may create difficulties with other employees. However, the Working Party did not feel that it would be fair to exclude them from the possibility of an award in all cases. In its view, the prospect of an award should be available in exceptional cases. If, for instance, an invention 
proves to be of outstanding value to the employer then, taking into account the remuneration of the employee, the effort and skill he has devoted to devising the invention and other relevant circumstances, it may be unjust totally to deprive him of all opportunity to obtain an award.

11. In the case of employee inventions which did not satisfy criteria (i)-(iii) and which, in the view of the Working Party, should therefore belong to the employee, the question of an award does not of course arise unless the employee offers rights in the invention and the employer accepts. In this event, the Working Party considered that the employee should have a statutory right to an award. In effect, this means that the employee will have an enforceable right to a review of any benefit that he derives from the agreement by means of which the employer acquired the rights in the employee's invention. It also means that an employer will not be able to rely on the agreement as conferring sufficient benefit on the employee if, under the terms of the statute, the employee is entitled to more. It should also be noted that it is not intended that the employee is to be obliged to offer his invention to his employer, nor is the latter to be compelled to take any rights in the invention or, if he does so, to patent it.

12. As regards the award, both in these cases and the exceptional cases referred to earlier, the Working Party considers that the employee's right should be to a fair share of the realised value to the employer of any patent for the invention. From this, it will be appreciated that, in the Working Party's view the award is to be related to the use made of any patent; although such use may, in many cases, provide financial benefit to the employer on the basis of which the award may be determined, the Working Party observed that many other inventions, particularly those which are government owned, are not exploited for profit. For this reason, the Working Party preferred to relate the award to the 'realised value' of the patent. The award is to be a fair share of this. In assessing the fair share, the Working Party agreed that all the circumstances of the case should be taken into account, but, with a view to giving guidance, a preference was also shown for referring specifically to the following relevant factors, namely:-

(i) the nature of the employee's duties and the remuneration he receives in respect of them;

(ii) the extent to which advice, equipment and other assistance is provided by the employer.

\section{Settling disputes}

13. The Working Party noted that the Court and Comptroller already have concurrent jurisdiction to deal with disputes concerning inventions made by employees. Industrial Tribunals are already overloaded and the Working Party did not recommend adding to their burden. It also did not consider that there was any justification for establishing by statute a new tribunal of a permanent nature or even providing by statute for an arbitration committee to be set up as occasion arises. It was felt that very few cases would be likely to arise in which the employer and his employee would not be able to settle their dispute themselves. This would especially be the case if, as was suggested, employers and employees could agree to set up as necessary a tribunal having a legally qualified chairman and two other persons with experience of industrial relations, one nominated by the employer and the other by the employee. Some members thought that this should be encouraged, but there was general agreement that it would not be right to deny 
access to the Court or Comptroller, and it was concluded that they should have jurisdiction to resolve all disputes arising under the proposed schemes.

\section{Collective agreements}

14. The Working Party was of the opinion that the statutory scheme should apply, notwithstanding any individual agreement to the contrary entered into between the employee or his employer. This applies especially to agreements entered into after the invention has been devised; agreements made at an earlier date are of course to have no legal effect, as proposed by the Banks Committee and accepted by the government.

15. However, the Working Party felt that it may be possible for an employee to obtain better treatment under a collective agreement. In view of this, it was agreed that a payment made by an employer under such an agreement should be regarded as satisfying any rights to an award which are available to the employee under the statutory scheme.

\section{R BOWEN \\ PATENT OFFICE}

\section{SEPTEMBER 1976}

1. (a) The right to any patent for an invention made by an employee who is mainly employed in the UK shall belong to the employer where:-

$i$ the invention arises from activity within the scope of the employee's normal duties;

ii the invention arises from activity within the scope of a special assignment which is outside the employee's normal duties;

iii the employee has, by virtue of his relation to the employer, a general obligation to further the interests of the employer's business as a whole.

(b) In all cases not covered sub-paragraph (a), the right to any patent for an invention made by an employee who is mainly employed in the UK shall belong to the employee.

2. (a) The employee referred to in paragraph 1 shall be entitled to payment by his employer of a fair share of the realised value to his employer of any patent for the invention made by the employee that may be obtained by the employer. In determining that share, regard shall be had to:-

$i$ the nature of the employee's duties and the remuneration he receives in respect of them including any remuneration derived from transfer of an invention as referred to in paragraph 1(b) to the employer;

ii the extent to which advice, equipment and other assistance is provided by the employer; and

iii all the other circumstances of the case.

(b) However, where the right to any patent belongs to the employer in accordance with paragraph 1(a), there shall be no payment over and above the employee's remuneration for his employment, other than in exceptional circumstances.

3. When employees agree collectively with an employer a scheme for determining what constitutes a fair share, a payment by the employer in conformity with that scheme is to be deemed to satisfy the requirements of paragraph 2 . 